\title{
ANALISIS PENGARUH KEBIJAKAN MONETER DAN KEBIJAKAN FISKAL REGIONAL TERHADAP STABILITAS HARGA DAN PERTUMBUHAN EKONOMI REGIONAL DI JAWA TIMUR (PERIODE 1995 - 2004)
}

\author{
Priadi Asmanto dan Soebagyo ${ }^{1}$
}

\begin{abstract}
This research analyzes the regional price stability in Indonesia, post the implementation of the UU No.23, 1999 and UU No.22, 1999. The first relates to the task of Bank Indonesia to stabilize the Rupiah, while the latter is about the fiscal decentralization from the center to the regional government.

The panel estimation technique is utilized on the case of East Java data, covering 6 classified periods, namely before crisis, period of crisis, prior decentralization and the period after decentralization. The result shows several findings, first, the fiscal decentralization and economic crisis have influence the price stability and economics growth significantly. Second, the join monetary and fiscal policies, has a significant impact on the regional growth and the price stability. Furthermore, this study shows a higher impact of the monetary policy than the fiscal policy.
\end{abstract}

Keywords: Monetary policy, regional, fiscal policy, panel, , decentralization, East Java.

JEL Classification: C 23, E31, H30, R50.

"Penulis adalah lulusan dan staf pengajar pada Universitas Airlangga; priadi.asmanto@yahoo.com, soebagyo@rad.net" 


\section{PENDAHULUAN}

\section{I.1. Latar Belakang Permasalahan}

Undang-Undang No.23 tahun 1999 tentang Bank Sentral, menyebutkan bahwa sasaran pokok kebijakan moneter Bank Indonesia terfokus kepada tujuan mencapai dan memelihara stabilitas nilai rupiah. Dimensi Internal dari memelihara kestabilan nilai rupiah diantaranya adalah mengendalikan laju inflasi dalam negeri, yang pada akhirnya juga berpengaruh pada pertumbuhan ekonomi. Dalam menjalankan tugas pokoknya, Bank Sentral menetapkan target inflasi yang akan dicapai sebagai landasan bagi perencanaan dan pengendalian sasaran-sasaran moneter. Pandangan mengenai inflasi, selalu identik dengan inflasi dalam konteks nasional. Namun, pada kenyataannya tingkat inflasi di tiap kota dalam satu negara, bahkan dalam satu propinsi sekali pun sering kali mengalami perbedaan. Isu penting yang berkaitan dengan inflasi pada tingkat regional pada saat ini adalah otonomi daerah.

Pada era otonomi daerah seperti pada saat ini, tugas Bank Indonesia sebagai otoritas moneter dapat diakatakan menjadi semakin berat². Undang-Undang mengenai otonomi daerah digunakan untuk memuat dua misi politik utama (Pratikno,1999)3. Kedua undang-undang mengenai otonomi daerah, memiliki implikasi bahwa pemerintah kabupaten maupun kota mempunyai andil besar dalam mengatur perekonomian daerahnya sendiri. Dengan demikian, kondisi perekonomian daerah akan sangat beragam dan tergantung pada potensi ekonomi masing-masing daerah beserta cara pengelolaannya. Hal ini juga berimplikasi pada kebijakankebijakan di tiap-tiap daerah yang dalam hal ini adalah kebijakan fiskal di tiap-tiap daerah, hal ini dikarenakan pemberlakuan desentralisasi fiskal sesuai dengan konsep otonomi daerah.

Kondisi yang beragam ditiap-tiap daerah semakin menambah pekerjaan dari tiap-tiap pemegang kebijakan, yang dalam hal ini Bank Indonesia sebagai otoritas moneter dan pemerintah daerah sebagai pemegang otoritas fiskal. Disatu sisi pemegang kebijakan moneter memiliki target menstabilkan harga, tetapi disisi lain tidak jarang kebijakan fiskal justru memberikan ruang gerak pada ketidakstabilan harga yang dikarenakan kebijakan-kabijakan pemerintah daerah yang ditujukan untuk mendorong pertumbuhan ekonomi di masing-masing

2 Otonomi daerah ditandai dengan dikeluarkannya Undang-Undang Nomor 22 tahun 1999 yang kemudian di revisi dengan UndangUndang Nomor 32 tahun 2004 tentang Pemerintahan Daerah dan Undang-Undang Nomor 25 tahun 1999 yang kemudian juga di revisi dengan Undang-Undang Nomor 33 tahun 2004 tentang Perimbangan Keuangan Pusat-Daerah,

3 Diantara misi politik tersebut pertama adalah untuk memberikan ruang partisipasi politik yang tinggi di tingkat daerah. Ini diwujudkan dengan desentralisasi politik dari pusat kepada daerah dan memberikan kesempatan dan keleluasaan politik kepada masyarakat daerah dengan memberikan kesempatan daerah untuk menikmati simbol-simbol utama dalam demokrasi lokal. Simbol utama lokal tersebut secara langsung maupun tidak langsung berkaitan juga dengan kebijakan fiskal, yang tidak terlepas dari keleluasaan politik di daerah. Misi politik kedua, untuk memberikan keleluasaan kepada daerah-daerah yang kaya sumber daya alam dan memiliki kecenderungan melepaskan diri dari negara kesatuan republik Indonesia, dengan memberikan akses yang lebih besar untuk menikmati sumber daya alam yang ada di daerah mereka masing-masing 
daerah. Beragamnya kondisi perekonomian di tiap daerah ini harus menjadi perhatian utama masing masing pemegang kebijakan dalam mengambil kebijakan. Hal tersebut dirasa sangat perlu dilakukan, dikarenakan adanya kekhawatiran terjadinya ketidakseimbangan kebijakan fiskal daerah dan kebijakan moneter Bank Indonesia (Simorangkir, 2005).

\begin{tabular}{|c|c|c|c|c|c|c|c|c|c|c|c|}
\hline & kemba & $\begin{array}{l}\text { angan } \\
\text { di Pi }\end{array}$ & $\begin{array}{l}\text { PDRB, } \\
\text { opinsi }\end{array}$ & $\begin{array}{l}\text { Tabel } \\
\text { Pertum } \\
\text { lawa T }\end{array}$ & $\begin{array}{l}\text { IV.1 } \\
\text { buhan } \\
\text { mur (1 }\end{array}$ & $\begin{array}{l}\text { Ekonc } \\
994-2\end{array}$ & $\begin{array}{l}\text { mi, da } \\
\text { 04) }\end{array}$ & Infla & & & \\
\hline TAHUN & 1994 & 1995 & 1996 & 1997 & 1998 & 1999 & 2000 & 2001 & 2002 & 2003 & 2004 \\
\hline Pertumbuhan Ekonomi & 7.23 & 8.18 & 8.26 & 5.02 & -16.1 & 1.21 & 3.26 & 3.33 & 3.41 & 4.11 & 5.44 \\
\hline Inflasi & 8.38 & 6.57 & 7.35 & 10.4 & 82.31 & 9.57 & 9.14 & 11.7 & 12.1 & 7.66 & 7.73 \\
\hline
\end{tabular}

Dari tabel IV.1. dapat dilihat pola PDRB, pertumbuhan ekonomi, dan inflasi di propinsi Jawa Timur selama 11 tahun terakhir. Selama periode sebelum krisis, rata rata pertumbuhan ekonomi adalah 7,17\%, sedangkan dalam periode yang sama inflasi rata-rata adalah sebesar $8,18 \%$. Selama periode ini inflasi dan pertumbuhan ekonomi propinsi Jawa Timur relatif stabil. Sedangkan pada tahun 1998 terjadi penurunan drastis pada pertumbuhan ekonomi yaitu sampai $-16,12 \%$, dan terjadi kenaikan drastis pula pada inflasi yaitu sebesar 82,31\%. Sejak tahun 1999 mulai terjadinya perbaikan perekonomian nasional membawa pengaruh pada perekonomian daerah. Selama periode 1999 - 2004, pertumbuhan ekonomi rata-rata adalah sebesar 3,46\%, meskipun lebih kecil dari pertumbuhan ekonomi rata-rata sebelum krisis, akan tetapi sedikit memberikan gambaran adanya perbaikan ekonomi. Demikian pula dengan inflasi rata-rata antara tahun 1999 - 2004 adalah 9,64\%, yang lebih besar daripada rata-rata inflasi sebelum krisis.

Penelitian ini akan mencoba untuk melihat dan mengidentifikasikan faktor-faktor yang menentukan laju inflasi dan pertumbuhan ekonomi regional di Jawa Timur, pada masa sebelum dan sesudah krisis serta sebelum otonomi daerah dan selama berlangsungnya otonomi daerah. Hal ini penting, karena laju inflasi dan pertumbuhan ekonomi merupakan indikator penting disektor riil dan merupakan salah satu dari beberapa tujuan pembangunan yang tidak terlepas dari perubahan yang terjadi di daerah, sedangkan krisis dan desentralisasi fiskal adalah variabel yang memungkinkan terjadinya fluktuasi-fluktuasi ekonomi.

Pada dasarnya, penelitian ini dilandasi dengan kerangka pemikiran bahwa tujuan pembangunan ekonomi di berbagai negara meliputi pertumbuhan ekonomi yang stabil, kesempatan kerja, stabilitas harga dan keseimbangan pada neraca pembayaran internasional. Dari dimensi regional, tujuan pembangunan nasional tidak jauh berbeda dengan tujuan 
pembangunan ekonomi di tiap-tiap daerah, terlebih dalam era desentralisasi fiskal seperti saat ini, terutama dalam hal menjaga stabilitas harga dan pertumbuhan ekonomi masing-masing daerah. Untuk mencapai tujuan tersebut pemerintah memiliki dua kebijakan ekonomi utama, yaitu kebijakan fiskal dan kebijakan moneter. Interaksi antara kedua kebijakan tersebut dalam mempengaruhi tujuan pembangunan (stabilitas harga dan pertumbuhan ekonomi) di daerah merupakan fokus utama dalam penelitian ini. Berbagai studi membuktikan bahwa ada keterkaitan antara kebijakan moneter dan kebijakan fiskal regional dengan tujuan-tujuan pembangunan ekonomi.

Dari uraian diatas, terdapat beberapa permasalahan pokok yang dapat diidentifikasi dan diterjemahkan dalam bentuk pertanyaan berikut: (i) Apakah shock ekonomi dan kebijakan desentralisasi fiskal signifikan dalam mempengaruhi pertumbuhan ekonomi dan stabilitas harga di Jawa Timur, (ii) Apakah variabel-variabel kebijakan moneter dan variabel-variabel kebijakan fiskal memiliki pengaruh yang signifikan terhadap laju inflasi regional dan pertumbuhan ekonomi regional di Jawa Timur, dan (iii) Faktor apakah yang paling dominan menyebabkan inflasi regional dan pertumbuhan ekonomi regional di Jawa Timur?

Hasil penelitian ini diharapkan dapat dijadikan sebagai bahan pertimbangan bagi masingmasing pemegang kebijakan yang berpengaruh terhadap dua indikator tersebut. Pada akhirnya diharapakan pula terjalinnya koordinasi yang erat antar pemegang kebijakan dalam mencapai tujuan inti dari pembangunan ekonomi nasional maupun regional, tanpa terkecuali di Jawa Timur yang merupakan bagian integral dari kondisi ekonomi secara nasional sesuai dengan konsep otonomi daerah. Dari indentifikasi faktor-faktor yang mempengaruhi laju inflasi dan pertumbuhan ekonomi regional di Jawa Timur ini, diharapakan dapat memudahkan masingmasing pemegang kebijakan dalam mengindentifikasikan tantangan dan hambatan serta peluang dalam penerapan kebijakan yang dirasa perlu dilakukan untuk mecapai tujuan inti tiap-tiap kebijakan.

Bagian selanjutnya mengulas landasan teori dan penelitian sebelumnya. Bab 3 membahas metodologi penelitian yang digunakan, sementara hasil dan analisis akan diulas pada Bab 4. Bab 5 akan mengulas kesimpulan dan rekomendasi kebijakan bagi pemerintah.

\section{TEORI}

\section{II.1. Inflasi, Kebijakan Fiskal, Kebijakan Moneter dan Desentralisasi Fiskal}

Inflasi dapat diartikan sebagai kenaikan tingkat harga barang secara umum (Mankiw, 2000; Mishkin, 2004). Penyebab terjadinya inflasi dapat dilihat dari beberapa sisi, sisi permintaan, sisi penawaran, atau campuran antara keduanya. Secara umum, penyebab terjadinya inflasi 
dapat diidentifikasi menjadi 3, yakni tarikan permintaan (Demand Pull Inflation), desakan biaya (Cost Push Inflation) atau karena inflasi negara lain yang tersalur melalui jaringan perdagangan (imported inflation). Proses dinamika harga ini dapat berlangsung secara natural melalui mekanisme pasar, maupun karena kebijakan. Salah satu contoh pergerakan harga yang diakibatkan oleh kebijakan adalah kebijakan kenaikan harga bahan bakar yang memicu kenaikan harga-harga barang dan jasa (administered price).

Kerangka umum yang sering dipergunakan dalam menganalisa interaksi simultan antara permintaan dan penawaran baik pada pasar barang dan pasar uang adalah kerangka IS-LM. Kerangka ini secara gamblang dapat menunjukkan bagaimana kebijakan moneter dan fiskal mampu mempengaruhi tingkat pendapatan atau output (Mankiw, 2000; Mishkin, 2004). Bagi bank sentral yang merupakan otoritas moneter, kebijakan yang ia pilih bergantung pada target, kondisi aktual perekonomian, kapasitas kebijakan dan pertimbangan tentang efektivitas kebijakan tersebut. Kebijakan moneter ini ditentukan secara terpusat oleh Bank Indonesia. Meskipun dalam formulasi kebijakannya Bank Indonesia sudah mempertimbangkan aspek regional, namun respon agen dan dampak pada masing-masing region tersebut sangat mungkin berbeda, dan ini sangat bergantung pada kondisi empirik masing-masing daerah

Pemerintah pada sisi lain, pemerintah selaku otoritas fiskal juga memiliki tipikal pertimbangan yang serupa, kecuali bahwa adanya pemisahan antara pemerintah pusat dan daerah akan membuka kemungkinan variasi kebijakan fiskal yang berbeda antara daerah satu dengan lainnya. Dalam perkembangannya, kebijakan fiskal dapat dibedakan menjadi 4 macam (Basri dan Sabri, 2003), yaitu (i) pembiayaan fungsional (functional finance), (ii) pengelolaan anggaran (the managed budget approach, (iii) stabilisasi anggaran otomatis (the automatic stabilizing budget) dan (iv) anggaran belanja berimbang (balanced budget approach). Kebijakan fiskal ini berada pada setiap level pemerintahan yakni pusat dan daerah, dan secara umum tertuang dalam Anggaran Pendapatan dan Belanja Negara (APBN) dan Anggaran Pendapatan dan Belanja Daerah (APBD) ${ }^{4}$.

Sejauh ini, tekad yang tertulis pemerintah dalam hal anggaran ini (Badan Analisa Fiskal, 2004) adalah, pertama, menempuh anggaran belanja seimbang dan dinamis di mana pengeluaran total tidak melebihi permintaan total. Kedua, Anggaran dibedakan menjadi anggaran rutin dan anggaran pembangunan. Tabungan pemerintah merupakan penerimaan dalam negeri di atas pengeluaran rutin yang diusahakan meningkat agar dapat mengurangi kebutuhan bantuan dan hutang luar negeri. Ketiga, dari sisi penerimaan anggaran, dasar

\footnotetext{
4 APBN maupun APBD bertindak sebagai alat pengatur urutan prioritas pembangunan dengan mempertimbangkan tujuan-tujuan yang ingin dicapai oleh usaha pembangunan.
} 
perpajakan diusahakan semakin luas lewat intensifikasi dan ekstensifikasi pemungutan pajak. Keempat, di sisi pengeluaran anggaran, prioritas diberikan pada kegiatan-kegiatan pembangunan dan bukan pada kegiatan-kegiatan rutin. Subsidi-subsidi semakin dikurangi baik untuk perusahaan-perusahaan pemerintah maupun terhadap barang konsumsi, sehingga akan menghemat pengeluaran. Kelima, kebijakan anggaran diarahkan pada sasaran untuk meningkatkan penggunaan barang-barang dan tenaga kerja dari dalam negeri, dengan tujuan agar produksi dalam negeri semakin meningkat. Dan keenam, dalam hubungannya dengan perluasan kesempatan kerja, produsen didorong untuk lebih menggunakan teknologi padat karya dengan sedikit menggunakan teknologi padat modal.

Peranan atau fungsi daripada pemerintah di bidang fiskal adalah untuk menciptakan stabilisasi ekonomi, pemerataan pendapatan, dan mengalokasikan sumber daya manusia. Khusus untuk fungsi stabilisasi dan pemerataan, akan lebih efektif apabila dilakukan pemerintah pusat, sedangkan fungsi alokasi akan lebih efektif dilakukan pemerintah daerah (Kuncoro, 1995).

Pertimbangan utama secara ekonomis mengapa fungsi alokasi lebih baik dilaksanakan oleh daerah adalah efisiensi yang diperoleh dari kedekatan pemerintah sebagai penyedia jasa bagi masyarakat (Badan Analisa Fiskal : 2004). Argumen ini merupakan salah satu titik tolak pemikiran dalam mendukung kebijakan desentralisasi fiskal. Pertimbangan lain yang mendukung desentralisasi fiskal adalah dalam rangka meningkatkan mobilisasi penerimaan sektor pemerintah secara keseluruhan, karena desentralisasi fiskal akan dapat memperluas jaringan pajak (tax net) sehubungan dengan keakuratan informasi basis pajak yang dimiliki oleh pemerintah daerah. Di samping itu, hal ini juga akan mendorong terjadinya distribusi penduduk dan ukuran daerah yang lebih baik, karena dimungkinkannya daerah memungut pajaknya sendiri.

Namun demikian, ada juga argumen yang tidak sejalan dengan kebijakan desentralisasi fiskal karena berpendapat bahwa kebijakan tersebut dapat menyebabkan fungsi stabilisasi menjadi lebih kompleks dan sulit dilakukan, sebagai akibat tidak terkontrolnya pengeluaran dan utang pemerintah daerah (Badan Analisa Fiskal : 2004). Alasan lain yang juga tidak mendukung kebijakan desentralisasi fiskal adalah berkaitan dengan pemerataan kesejahteraan antar penduduk dan antar wilayah. Hal ini didasarkan pada perbedaan potensi ekonomi dan sumber daya yang dimiliki oleh masing-masing daerah terdapat ketimpangan, sehingga desentralisasi fiskal akan cenderung memperburuk ketimpangan kesejahteraan masyarakat. Untuk itu, dengan sistem fiskal yang sentralistik, pemerataan antarwilayah atau antardaerah dapat dilakukan, dengan cara mentransfer sumber daya dari daerah kaya kedaerah miskin. 


\section{II.2. Penelitian Sebelumnya}

Terdapat beberapa penelitian mengenai pengaruh kebijakan moneter maupun kebijakan non moneter (fiskal) secara regional, terlebih pasca penerapan otonomi daerah. Penelitianpenelitian tersebut cenderung membahas pengaruh kebijakan moneter dan non moneter terhadap stabilitas harga secara regional.

Penelitian pertama, adalah penelitian yang dilakukan oleh Iskandar P. Simorangkir, dkk (2005) mengenai indentifikasi faktor penentu inflasi regional di era otonomi daerah. Penelitian tersebut menggunakan sampel 43 kota di Indonesia. Model yang digunakan dalam penelitian tersebut dengan 2 kombinasi. Teknik pertama adalah teknik varian decomposition yang digunakan untuk mengetahui faktor penyebab inflasi regional yang paling dominan dan kedua adalah model data panel yang digunakan untuk mengetahui faktor yang paling menentukan inflasi didaerah, dalam hal ini faktor moneter atau non moneter. Hasil penelitian yang menyimpulkan bahwa secara umum faktor non-moneter memiliki predictif power yang lebih tinggi daripada faktor moneter. Sedangkan untuk faktor yang paling menentukan inflasi di daerah adalah faktor non-moneter yaitu PAD, pengeluaran rutin dan biaya transportasi.

Penelitian kedua, adalah penelitian yang dilakukan oleh Riski Satya Budi \& Frita Amrita (2006) mengenai stabilitas harga, konvergensi inflasi dan otonomi daerah. Penelitian tersebut menggunakan data inflasi 26 propinsi di Indonesia yang digunakan untuk melakukan estimasi tingkat konvergensi inflasi di Indonesia. Teknik analisis yang dipakai adalah dengan pendekatan teknik data panel yang dikembangkan oleh Levin dan Lin (1992) serta Levin dan Lin (1993), dengan membedakan antara periode sebelum dan sesudah penerapan kebijakan otonomi daerah. Penelitian ini menghasilkan kesimpulan bahwa inflasi antar daerah di Indonesia tidak menyimpang jauh, tetapi cenderung konvergen. Sedangkan pada periode otonomi daerah, konvergensi inflasi antar daerah di Indonesia relatif cepat bila dibandingkan dengan periode sebelum otonomi daerah.

Penelitian ketiga, adalah penelitian yang dilakukan oleh Hery Sulistio Sriwiyanto dan Tetuko Rawidyo Putro (2006) mengenai tantangan dan prospek implementasi kebijakan stabilitas harga dengan pendekatan model new-keynesian monetery policy dalam perspektif otonomi daerah. Penelitian ini secara empiris membuktikan di 40 kota di Indonesia selama periode 1993 - 2003. Model yang digunakan adalah melalui pendekatan New Keynesian Phillips Curve, model tersebut selanjutnya digunakan adalah model E-APC dan model backward-looking Phillips Curve. Berdasarkan hasil estimasi dalam penelitian tersebut ditemukan bahwa secara umum inflasi yang terjadi di masing-masing daerah selama kurun waktu 1993-1997 ditentukan oleh harapan inflasi serta inflasi inersia. Setelah era reformasi atau kurun waktu 1999-2003 perubahan inflasi selain ditentukan oleh inflasi harapan dan inflasi inersia juga ditentukan oleh kesenjangan output. Terdapat tingkat signifikansi hubungan antara variabel perubahan struktural 
yang dipengaruhi oleh perubahan strutkural dengan diberlakukannya kebijakan desentralisasi fiskal. Peran kebijakan desentralisasi berpengaruh terhadap perilaku inflasi daerah. Berdasarkan hasil estimasi regresi,model New-Keynesian secara regional dan secara empiris berlaku dalam ekonomi Indonesia pada periode setelah krisis.

Penelitian keempat, adalah penelitian yang dilakukan oleh Rifai Afin (2006), mengenai stabilitas dan dispersi harga dalam skema otonomi daerah di indonesia. Dalam penelitian ini pendekatan yang digunakan adalah teknik cross sectional untuk melihatkonvergensidan cross regional dispersion untuk melihat pengaruh rata-rata inflasi terhadap standar deviasi setiap periode waktu pada data cross inflation. Data yang dipergunakan dalam penelitian ini berupa data panel dari observasi bulanan terhadap IHK di 43 kabupaten dan kota di Indonesia sebelum otonomi daerah April 1998 sampai Desember 1999 dan dalam skema otonomi daerah Januari 2000 sampai September 2005.

Terdapat dua hal penting yang dapat disimpulkan dari penelitian ini. Pertama, Inflasi di 43 kota di Indonesia menyimpang jauh antar satu sama lain dan cenderung dinvergen setelah diterapkannya skema otonomi daerah tetapi konvergen sebelum diterapkannya otonomi daerah. Kedua, Model Dispersi mensyaratkan otoritas moneter untuk melihat bagaimana perilaku dispersi atau sebaran inflasi di daerah sebelum mentargetkan inflasi karena tentu saja akan membawa implikasi negatif jika tidak memperhitungkan adanya perilaku dispersi.

Penelitian kali ini pada dasarnya berbeda dengan penelitian-penelitian yang pernah dilakukan seperti disebutkan sebelumnya. Pertama, penelitian ini menggunakan obyek yang lebih mikro, dimana sampel penelitian merupakan daerah-daerah tingkat dua di Jawa Timur. Kedua, penelitian ini memasukkan variabel-variabel kebijakan moneter dan kebijakan fiskal. Ketiga, penelitian ini menggunakan variabel inflasi dan variabel pertumbuhan ekonomi sebagai variabel yang dipengaruhi variabel kebijakan moneter dan kebijakan fiskal regional. Keempat, variabel shock ekonomi dan adanya perubahan kebijakan diperhitungkan dalam penelitian ini. Dengan demikian, penelitian ini lebih mendasarkan pada pemikiran bahwa obyek makroekonomi regional yang diteliti tidak hanya dipengaruhi kebijakan regional, akan tetapi dipengaruhi juga oleh kebijakan moneter yang sifatnya nasional yang tentunya berdampak pula pada kondisi makroekonomi regional di daerah penelitian.

\section{METODOLOGI}

\section{III.1. Data}

Pendekatan yang digunakan dalam penelitian ini adalah pendekatan kuantitatif dengan metode regresi data panel. Jenis data yang digunakan dalam penelitian ini adalah data sekunder 
dan merupakan data panel (gabungan antara data time-series dan cross section), dalam bentuk tahunan. Data time series yang digunakan dimulai dari periode 1995 sampai 2004 (10 tahun). Sedangkan data cross section-nya adalah 25 daerah tingkat dua di Jawa Timur. Data cross section yang digunakan adalah sesuai dengan kriteria Bank Indonesia yaitu data dari seluruh daerah tingkat dua di Jawa Timur, kecuali Pacitan, Ponorogo, Trenggalek, Nganjuk dan Sampang. Lima daerah tersebut di kategorikan oleh Bank Indonesia sebagai daerah tingkat dua lainnya, sehingga dalam penelitian ini tidak dimasukkan sebagai sampel penelitian.

Data yang digunakan dalam penelitian ini diperoleh secara online Laporan Realisasi APBD Propinsi-propinsi di Indonesia yang di sediakan dalam situs Departemen Keuangan dan secara manual dari Indikator Ekonomi, Kabupaten dan Kota dalam Angka dan Produk Domestik regional Bruto menurut Kabupaten dan Kota di Jawa Timur (terbitan Biro Pusat Statistik), Statistik Ekonomi Keuangan Indonesia (SEKI), Statistik Ekonomi Keuangan Daerah (SEKDA) terbitan Bank Indonesia, berbagai edisi dan disamping juga data yang berasal dari sumber-sumber lain yang relevan digunakan dalam penelitian ini.

\section{III.2. Metode Data Panel}

Model ini lebih tepat ketika terdapat potensi masalah interkorelasi diantara variabelvariabel bebas yang pada dapat mengakibatkan hasil penaksiran. (Arif, 1992). Pada dasarnya ada tiga teknik untuk meregresi data panel ${ }^{5}$, yaitu: pendekatan OLS biasa (Pooled Least Square), pendekatan efek tetap (Fixed Effect Model) dan pendekatan efek acak (Random effect Model). Diantara ketiga teknik tersebut, pendekatan Fixed Effect Model (FEM) yang akan digunakan untuk mengestimasi model penelitian pada skripsi ini.

Ada beberapa alasan mengapa penelitian ini menggunakan pendekatan Fixed Effect Model (FEM) dalam mengestimasi model penelitian dan bukan kedua teknik lainnya. Pertama, pendekatan PLS pada dasarnya memiliki kesamaan dengan OLS biasa yang hanya memiliki satu konstanta untuk keseluruhan daerah, sedangkan fundamental perekonomian, ukuran skala perekonomian, dan struktur perekonomian tiap-tiap cross section tidaklah sama. Kedua, teknik REM tidak dipakai dengan alasan, teknik ini mengasumsikan bahwa unit observasi crosssection $^{6}$ dalam data panel merupakan sampel random yang mewakili populasi (Grifiths, 2001), sedangkan 25 daerah sampel dalam penelitian ini tidak dipilih secara random, akan tetapi dipilih sesuai dengan kriteria Bank Indonesia.

\footnotetext{
6 Lihat : Baltagi, 2002 ; Gujarati, 2003 ; Maddala ; 1993 ; Pindyck dan Rubinfeld, 1998

6 Dalam kasus penelitian ini adalah daerah-daerah tingkat dua di Jawa Timur, tanpa membedakan kota maupun kabupaten.
} 
Pada dasarnya penggunaan metode data panel memiliki beberapa keunggulan (Gujarati, 2003). Pertama, panel data mampu memperhitungkan heterogenitas individu secara eksplisit dengan mengijinkan variabel spesifik individu. Kemampuan mengontrol heterogenitas individu ini, pada gilirannya menjadikan data panel dapat digunakan untuk menguji dan membangun model perilaku yang lebih kompleks. Kedua, jika efek spesifik signifikan berkorelasi dengan variabel penjelas lainnya, penggunaan panel data akan mengurangi masalah omitted variables secara substansial. Ketiga, data panel mendasarkan diri pada observasi cross section yang berulangulang (time series), sehingga metode data panel cocok untuk digunakan sebagai study of dynamic adjustment. Keempat, tingginya jumlah observasi memiliki implikasi pada data yang lebih informatif, lebih variatif, kolinieritas antar variabel yang semakin berkurang, dan peningkatan derajat kebebasan (degree of freedom), sehingga dapat diperoleh hasil estimasi yang lebih efisien. Kunggulan-keunggulan tersebut diatas memiliki implikasi pada tidak diperlukannya pengujian asumsi klasik dalam model data panel, sesuai apa yang ada dalam beberapa literatur yang digunakan dalam penelitian ini (Maddala, 1998; Pindyck \& Rubinfeld, 1991; dan Gujarati, 2003).

\section{III.3. Metode Dummy Variabel}

Untuk tujuan mengatasi permasalahan-permasalahan yang timbul dalam analisis regresi. Dalam analisis awal, dua model tersebut di atas diaplikasikan dengan memasukkan dua variabel dummy berupa krisis ekonomi dan otonomi daerah. Hal ini dikarenakan selama periode penelitian terdapat dua hal penting tersebut memungkinkan adanya bias analisis jika hanya melakukan regresi tanpa membedakan adanya shock ekonomi dan perubahan kebijakan, yaitu krisis ekonomi dan otonomi daerah.

Menurut Gujarati (2003), untuk mengatasi permasalahan yang timbul akibat adanya shock ekonomi atau perubahan kebijakan, dimungkinkan 4 hal untuk mengatasinya. Pertama, Coincident regression, langkah ini mengasumsikan bahwa intercep dan slope koefisien adalah sama pada sebelum dan sesudah shock. Kedua, Parallel regression, langkah ini mengasumsikan bahwa intercep berbeda dan slope koefisien adalah sama pada sebelum dan sesudah shock. Ketiga, Concurrent regression, langkah ini mengasumsikan bahwa intercep sama dan slope koefisien adalah berbeda pada sebelum dan sesudah shock. Dan keempat, Desimiliar regression, langkah ini mengasumsikan bahwa antara intercep dan slope koefisien adalah berbeda pada sebelum dan sesudah shock.

\section{III.4. Model Empiris}

Model persamaan yang akan diestimasi dengan teknik ini ialah model yang dimodifikasi dari penelitian Simorangkir et al. (2005). Adapun model tersebut terbagi menjadi 2 sebagai berikut : 


\section{Model Inflasi}

$$
\begin{aligned}
& \text { INFLASI }_{i t}=\beta_{0}+\beta_{1} \text { GPAD }_{i t}+\beta_{2} \text { GER }_{i t}+\beta_{3} \text { GED }_{i t}+\beta_{4} \text { GDPK }_{i t}+ \\
& \beta_{5} \text { GKREDIT }_{i t}+\beta_{6} \text { BUNGA }_{i t}+\beta_{7} \text { DKRISIS }_{i t}+\beta_{8} \text { DOTODA }_{i \nless} \text { IV }_{4} 1 \phi_{i t}
\end{aligned}
$$

\section{Model Pertumbuhan Ekonomi}

$$
\begin{aligned}
& \text { GPDRB }_{i t}=\beta_{0}+\beta_{1} \text { GPAD }_{i t}+\beta_{2} \text { GER }_{i t}+\beta_{3} G E D_{i t}+\beta_{4} \text { GDPK }_{i t}+ \\
& \beta_{5} \text { GKREDIT }_{i t}+\beta_{6} \text { BUNGA }_{i t}+\beta_{7} \text { DKRISIS }_{i t}+\beta_{8} \text { DOTODA }_{i t}+e_{i t}
\end{aligned}
$$

dimana :

$$
\begin{aligned}
& \text { INFLASI }_{i t} \quad=\text { Inflasi di daerah } i \text { pada periode } t \text {; } \\
& G_{P D R B} \quad=\text { Pertumbuhan PDRB riil daerah } i \text { pada periode } t \text {; } \\
& G_{i t} \quad=\text { Pertumbuhan Pengeluaran rutin daerah } i \text { pada periode } t ; \\
& G E D_{i t} \quad=\text { Pertumbuhan Pengeluaran pembangunan daerah } i \text { pada periode } t \text {; } \\
& G P A D_{i t} \quad=\text { Pertumbuhan Pendapatan asli daerah } i \text { pada periode } t \text {; } \\
& G_{\text {GPK }} \quad=\text { Pertumbuhan Dana pihak ketiga yang dihimpun perbankan umum daerah } i \\
& \text { pada periode } t \text {; } \\
& \text { GKREDIT }_{i t}=\text { Pertumbuhan Kredit yang disalurkan perbankan umum daerah } i \text { pada periode } t \text {; } \\
& B U N G A_{i t} \quad=\text { Suku bunga riil di daerah } i \text { pada periode } t \text {; } \\
& \beta_{0}=\ldots \ldots \ldots=\beta_{n}=\text { Koefisien regresi; } \\
& \mathrm{e}_{i t} \quad=\text { Koefisien pengganggu } \text {. } \\
& \text { DKRISIS }_{i t} \quad=\text { Dummy krisis; } \\
& D_{O T O D A_{i t}}=\text { Dummy otonomi daerah; }
\end{aligned}
$$

Jika model IV.1. dan model IV.2. memiliki koefisien dua variabel dummy-nya adalah signifikan, maka dalam analisis selanjutnya analisis akan terbagi dalam 5 bagian analisis, sesuai dengan kondisi-kondisi fluktuasi ekonomi dan perubahan kebijakan selama periode penelitian. Adapun pembagian periode-periode tersebut di antaranya adalah keseluruhan periode, periode sebelum krisis, periode setelah krisis, periode sebelum otonomi daerah, dan periode setelah berlakunya otonomi daerah.

Akan tetapi jika koefisien dari dua dummy variabelnya tidak signifikan, maka analisis selanjutnya hanya melakukan analisis keseluruhan periode dengan tetap menggunakan model IV.1 dan IV.2. dengan tanpa membedakan periode penelitian (tanpa memasukkan variabel dummy), dengan kata lain adanya shock ekonomi dan perubahan kebijakan diabaikan. 
Setelah model penelitian diestimasi maka akan diperoleh nilai dan besaran dari masingmasing parameter dalam model di atas. Nilai dari parameter positif atau negatif selanjutnya akan digunakan untuk menguji hipotesis penelitian. Dalam konteks penelitian ini yang ingin diketahui ialah : pertama, apakah variabel-variabel kebijakan moneter, kebijakan fiskal, shock ekonomi dan perubahan kebijakan (otonomi daerah) memiliki pengaruh signifikan terhadap inflasi dan pertumbuhan ekonomi. Kedua, faktor apakah yang paling dominan menentukan inflasi daerah dan pertumbuhan ekonomi daerah-daerah di Jawa Timur (faktor moneter atau faktor fiskal daerah).

\section{HASIL DAN ANALISIS}

Pembahasan pada bagian ini diawali dengan deskripsi empiris atas kondisi aktual pada perekonomian Jawa Timur. Pada bagian berikutnya, hasil dari estimasi model akan diuraikan, termasuk kesesuainnya dengan deskripsi empiris sebelumnya.

\section{IV.1. Deskripsi Empiris}

\section{IV.1.1. Produk Domestik Regional Bruto dan Inflasi}

Salah satu hal penting dalam pembangunan dan juga merupakan salah satu tujuan pembangunan nasional adalah pertumbuhan ekonomi yang tinggi. Dalam konteks pertumbuhan ekonomi daerah hal tersebut juga tidak jauh berbeda. Tiap-tiap daerah tentunya menginginkan dan menjadikan pertumbuhan ekonomi menjadi salah satu sasaran dalam pembangunan daerahnya.

Seperti terlihat dalam Gambar IV.1. dalam kurun waktu 11 tahun terakhir ini, pertumbuhan ekonomi 25 daerah di Jawa Timur memiliki pergerakan ke arah yang sama, meskipun besarnya pertumbuhan ekonominya berbeda-beda. Pergerakan pertumbuhan ekonomi yang cenderung sama tersebut mengindikasikan bahwa struktur perekonomian yang ada masih memiliki kesamaan antar daerah. Seperti halnya variabel-variabel makro yang lainnya, pertumbuhan ekonomi juga memiliki fluktuasi yang sangat tajam dan terjadi pada periode yang sama yakni periode krisis ekonomi 1997/1998. Demikian pula pada periode-periode selanjutnya, pertumbuhan ekonomi masih memiliki pergerakan yang sama antar daerah, dimana pertumbuhan tersebut cenderung mengarah pada arah yang positif, meskipun besarnya masih cenderung lebih kecil dibanding periode sebelum krisis.

Seperti halnya dengan pertumbuhan ekonomi yang merupakan salah satu tujuan pembangunan, stabilitas harga juga merupakan salah satu sasaran dari tujuan pembangunan, 


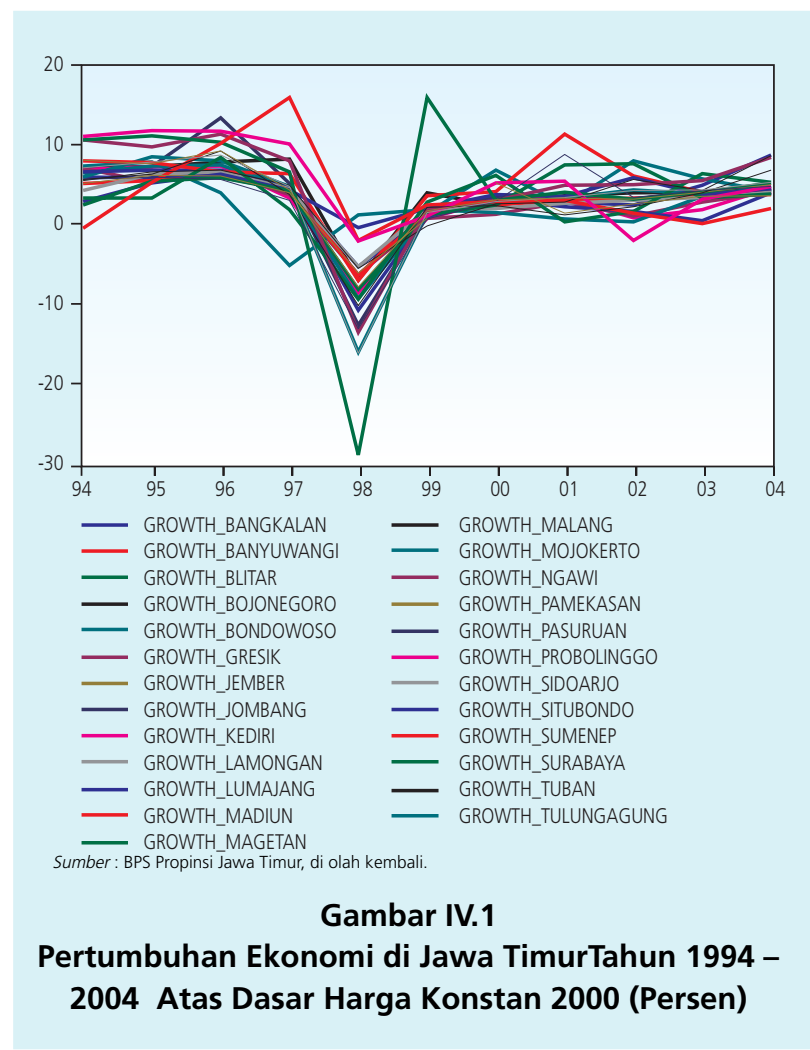

baik secara nasional maupun secar regional. Salah satu ukuran stabilitas harga dapat dilihat dari inflasi yang terjadi di daerah-daerah, dimana jika inflasi memiliki kecenderungan rendah dan stabil dapat dikatakan harga-harga stabil, demikian pula sebaliknya.

Stabilitas harga yang tercermin dari inflasi tersebut dapat dilihat dari dua pendekatan. Pendekatan yang pertama adalah pendekatan Indeks Harga Konsumen, sedangkan pendekatan yang kedua adalah pendekatan perubahan deflator PDRB. Kedua pendekatan tersebut memiliki arti yang sama dalam hal cerminan inflasi, meskipun besar dan pengertiannya sedikit memiliki perbedaan.

Perkembangan inflasi 25 daerah di Jawa Timur tidak jauh berbeda dengan inflasi yang terjadi secara nasional. Secara umum dalam Gambar IV.2. berikut terlihat bahwa inflasi puncak terjadi pada tahun 1998 yakni mencapai angka tertinggi sampai 80\%. Pola perkembangan inflasi antar daerah di Jawa Timur pada dasrnya tidak memiliki perbedaan yang jauh, atau dengan kata lain memiliki kecenderungan bergerak ke arah yang sama. Dari Gambar IV.2. juga dapat dilihat bahwa inflasi antar daerah sebelum terjadi krisis ekonomi menunjukkan arahan yang lebih stabil jika dibandingkan dengan inflasi setelah terjadinya krisis ekonomi yang relatif bervariasi antar daerah. Hal ini mengindikasikan bahwa kebijakan fiskal regional yang cenderung 


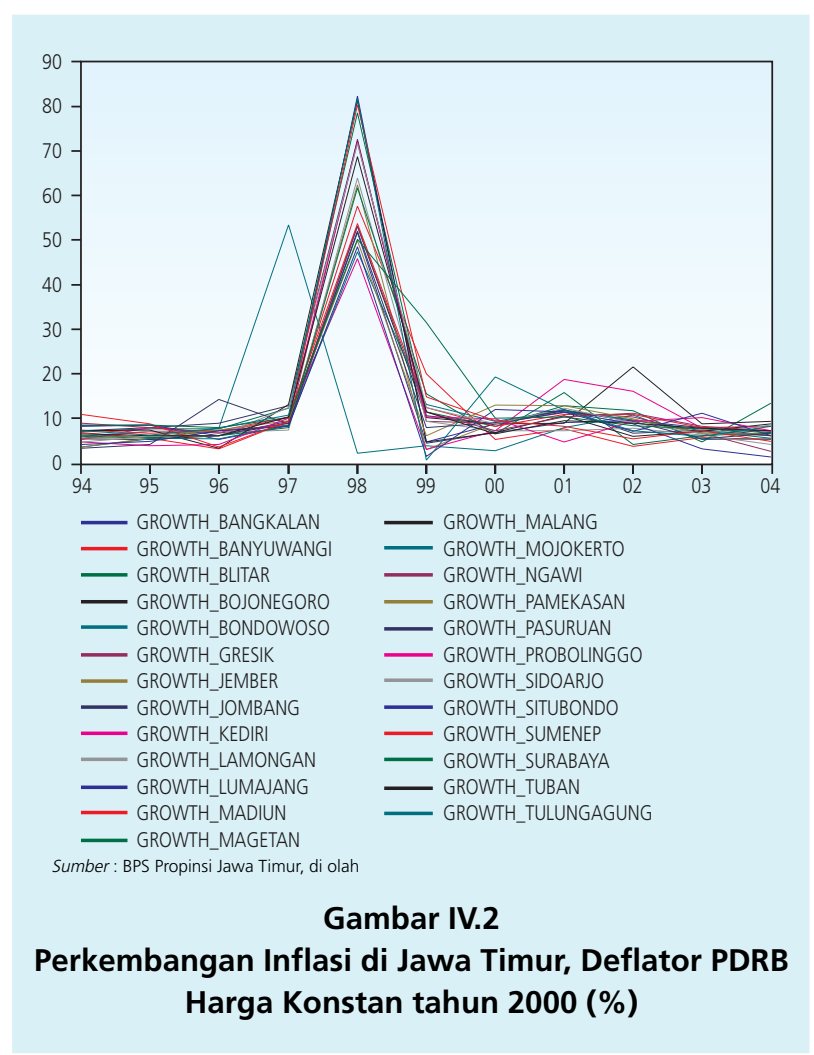

berbeda pasca diterapkannya desentralisasi fiskal antara daerah membawa implikasi yang berbeda-beda pula antara daerah satu dengan daerah lainnya.

\section{IV.1.2. Perkembangan Indikator Kebijakan Moneter 25 Daerah Tingkat II di Jawa Timur}

Indikator moneter dari sudut pandang regional propinsi Jawa Timur diantaranya adalah suku bunga, dana pihak ketiga yang dihimpun oleh perbankan di daerah dan kredit yang disalurkan oleh perbankan di daerah.

Suku bunga riil merupakan selisih antara suku bunga SBI 1 bulan dengan inflasi dengan pendekatan PDRB deflator. Pandangan ini dengan asumsi bahwa tiap-tiap daerah memiliki tingkat inflasi yang berbeda, sehingga suku bunga yang berlaku secara riil didaerah juga berbeda.

Secara umum Gambar IV.3. mengilustrasikan bahwa suku bunga secara riil berfluktuasi tajam pada periode krisis ekonomi 1997/1998. Fluktuasi tersebut terbalik dengan pola pergerakan suku bunga SBI 1 bulan, dimana secara riil suku bunga di daerah penelitian turun 


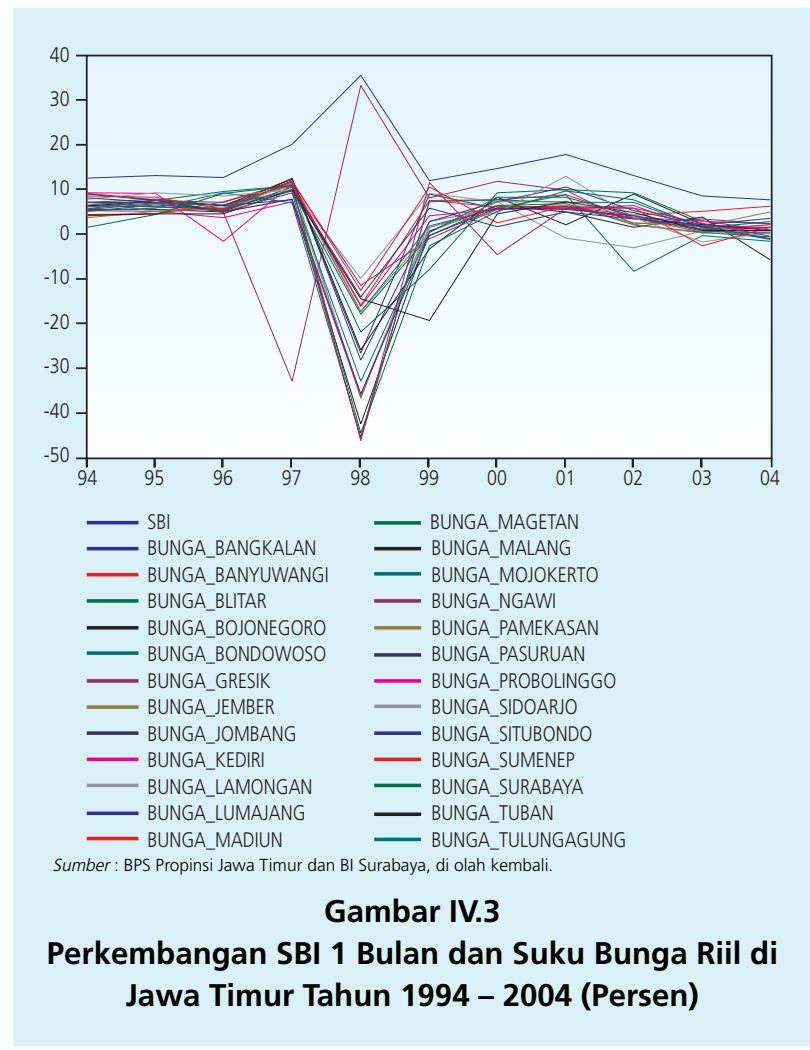

hingga pada titik terendah berkisar pada angka $-48 \%$, sementara rate SBljustru mengalami kenaikan drastis hingga 35,54\%. Hal tersebut merupakan indikasi kuat bahwa dalam periode krisis, salah satu instrumen penting dalam mengendalikan inflasi adalah melalui jalur suku bunga, sehingga secara nominal bunga mengalami kenaikan yang sangat tajam pada periode krisis untuk tujuan mengendalikan inflasi.

Indikator kedua dari kondisi moneter adalah kredit. Kredit yang disalurkan perbankan di Jawa Timur merupakan proxy dari jumlah uang beredar di daerah. Kredit merupakan proxy jumlah uang beredar dari sisi permintaan uang. Dalam bagian ini akan di ilustrasikan perkembangan kredit di 25 daerah.

Dari Gambar IV.4. terlihat bahwa pertumbuhan kredit di tiap-tiap daerah bergerak pada arah yang sama. Pergerakan pertumbuhan kredit tersebut mengalami fluktuasi yang cukup tajam pada periode krisis, yaitu antara tahun 1997 - 1999. Pada periode tersebut jumlah kredit yang disalurkan oleh perbankan di daerah mengalami kenaikan. Hal ini disebabkan adanya krisis ekonomi yang tentunya membutuhkan banyak kucuran dana oleh perbanlkan untuk mempertahankan unit-unit ekonomi penting dari shock yang berupa krisis ekonomi, disamping 


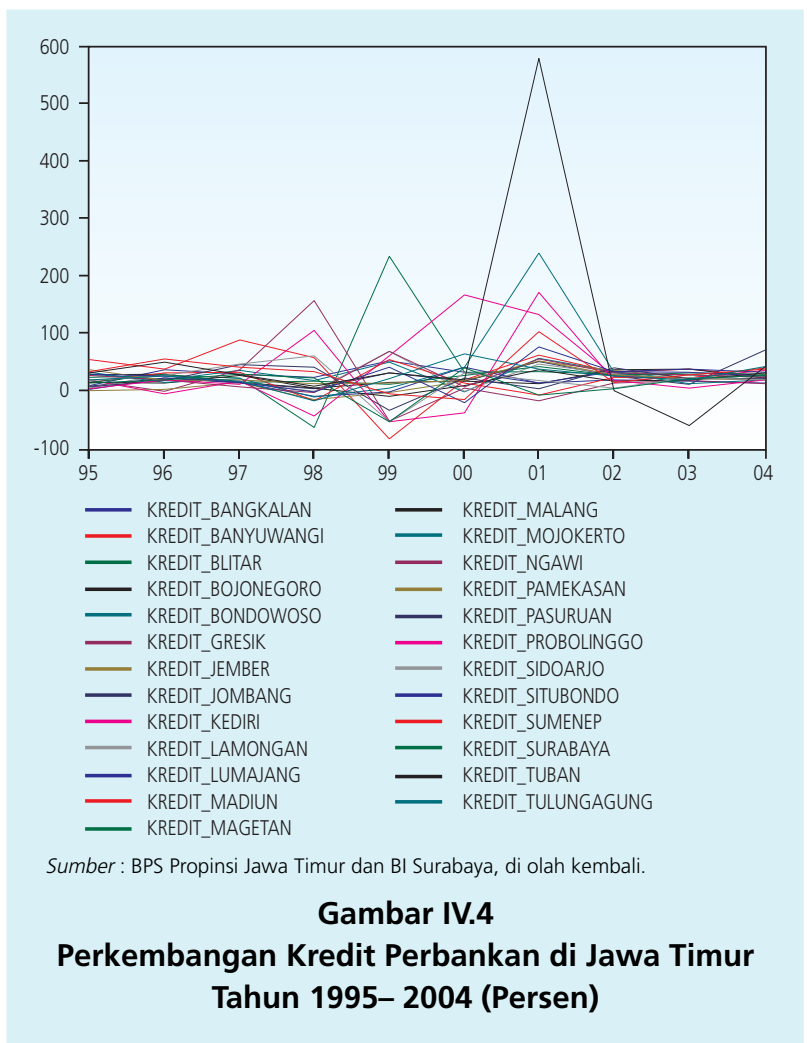

juga kredit yang sifatnya untuk konsumsi. Demikian pula dengan perekonomian yang secara nasional juga mengalami hal yang sama yaitu krisis ekonomi pada periode 1997/1998, yang imbasnya juga dirasakan dalam sistem perekonomian daerah-daerah di Jawa Timur.

Indikator berikutnya adalah dana pihak ketiga yang merupakan ukuran potensi kebijakan moneter di tiap daerah. Sebagaimana kredit sebai proxy jumlah uang beredar di daerah, DPK juga dapat digunakan sebagai proxy jumlah uang beredar. Lebih tepatnya sebagi proxy dari penawaran uang. Dana pihak ketiga terdiri dari tabungan dan deposito.

Secara umum Gambar IV.5. menunjukkan bahwa pertumbuhan dana yang di himpun oleh perbankan di daerah bergerak ke arah yang sama. Meskipun besarnya jumlah nominal masing-masing dana yang di himpun di tiap-tiap daerah berbeda, namun arah pertumbuhan dana yang dihimpun perbankan di tiap-tiap daerah cenderung memiliki kesamaan, yaitu semakin mengalami kenaikan setiap tahunnya. Hal ini dikarenakan kebutuhan dana untuk disalurkan dalam bentuk kredit setiap tahunnya mengalami kenaikan, terlebih selama periode krisis ekonomi 1997/1998 yang sangat membutuhkan kucuran dana demi mempertahankan kegiatan ekonomi yang ada di masyarakat. 


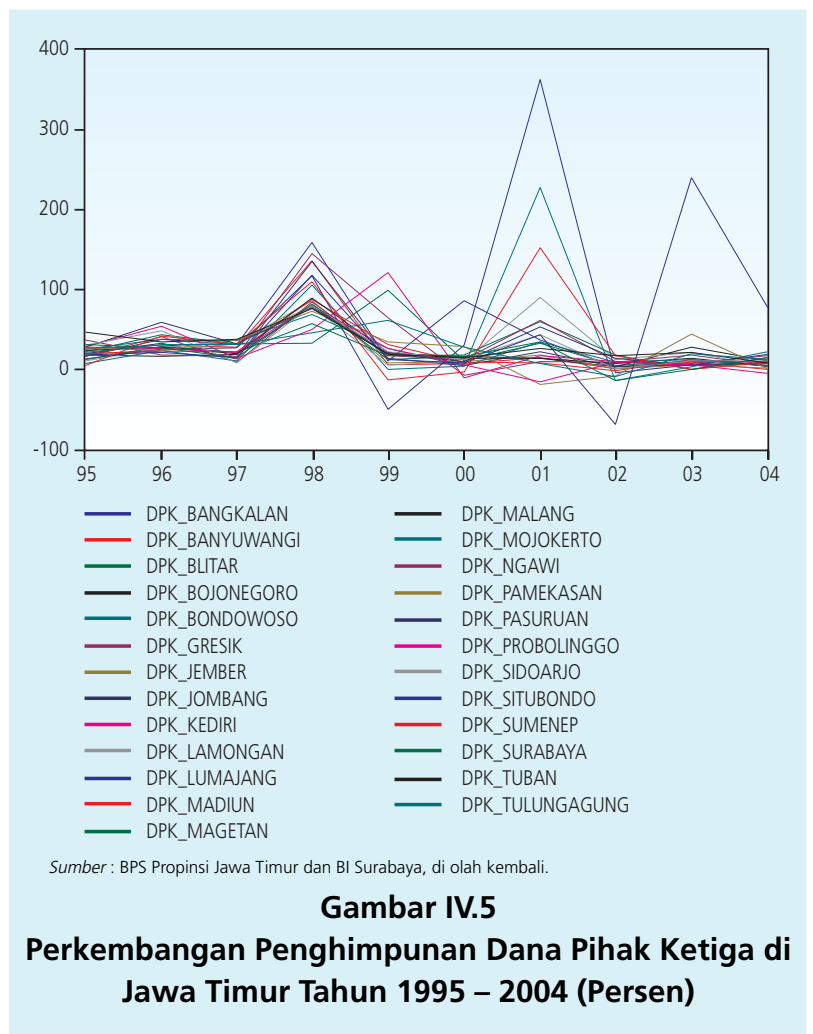

\section{IV.1.3. Perkembangan Variabel-varaibel Kebijakan Fiskal 25 Daerah Tingkat II di Jawa Timur}

Perkembangan kebijakan fiskal di daerah tidak terlepas dari dua momen penting dalam perekonomian nasional, yaitu krisis ekonomi dan kebijakan desentralisasi fiskal. Kedua hal tersebut secara langsung maupun tidak langsung mempengaruhi variasi dan fluktuasi pergerakan kebijakan fiskal, baik dalam hal jumlah maupun dalam hal efek terhadap pembangunan ekonomi. Ukuran potensi fiskal pada dasarnya banyak jenis dan macamnya, akan tetapi dalam penelitian ini penulis menggunakan pengeluaran pembangunan, pengeluaran rutin dan pendapatan asli daerah sebagai ukuran potensi fiskal di daerah penelitian.

Indikator pertama tentang perkembangan dan pergerakan kebijakan fiskal tersebut adalah pendapatan asli daerah (PDA). Sebagai salah satu ukuran potensi fiskal daerah, pendapatan asli daerah merupakan salah satu hal penting dalam hal upaya penggalian potensi daerah. Pentingnya hal tersebut tercermin dari semakin gencarnya tiap-tiap daerah dalam hal penggalian potensi tersebut untuk mengisi besarnya nilai pendapatan asli daerahnya, terlebih setelah diterapkannya kebijakan otonomi daerah. Meskipun demikian daerah-daerah cenderung tidak 


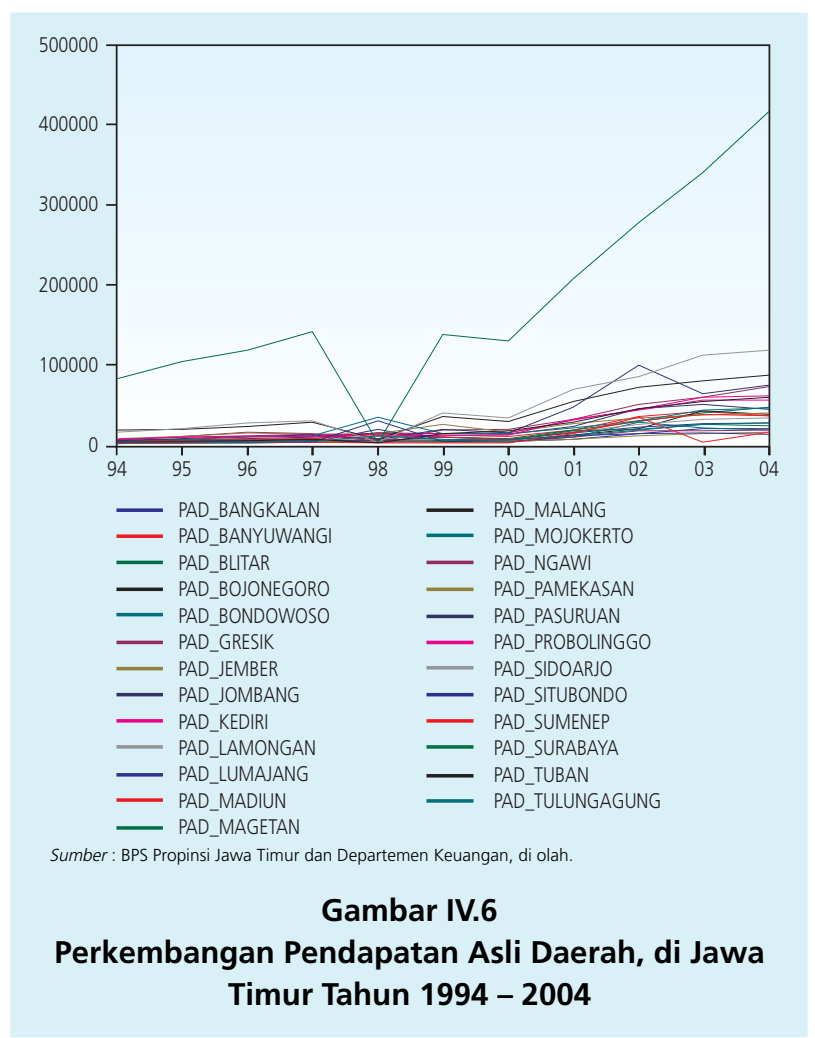

memperhatikan efek ekonomi di sektor riil dari kebijakan peningkatan pendapatan asli daerahnya. Ilustrasi perkembangan pendapatan asli daerah di 25 daerah penelitian di ilustrasikan dalam gambar IV.6.

Secara umum pertumbuhan pendapatan asli daerah tiap-tiap daerah bergerak pada arah yang sama. Hal ini dapat dilihat dari Gambar IV.6, dimana pada periode krisis 1997 - 1999 pendapatan asli daerah tiap tiap daerah mengalami pergerakan yang cenderung menurun, meskipun tidak secara keseluruhan daerah penelitian. Demikian pula pada periode setelah penerapan kebijakan desentralisasi fiskal yang menunjukkan pergerakan pendapatan asli daerah yang cenderung mengalami kenaikan. Hal ini mengindikasikan bahwa sejak diterapkannya kebijakan otonomi daerah, daerah-daerah di Jawa Timur cenderung untuk meningkatkan pendapatan asli daerahnya. Kecenderungan peningkatan pendapatan asli daerah adalah implikasi dari kebijakan desentralisasi fiskal (otonomi daerah) dengan tujuan meningkatkan pembangunan daerah demi kesejahteraan masyarakat.

Ukuran indikator kebijakan fiskal daerah yang diapakai selanjutnya adalah pengeluaran rutin daerah. Pengeluaran rutin ditujukan untuk pembelanjaan yang sifatnya berkelanjutan, seperti halnya penggajian pegawai dan subsidi. Pada dasarnya pengeluaran rutin daerah 


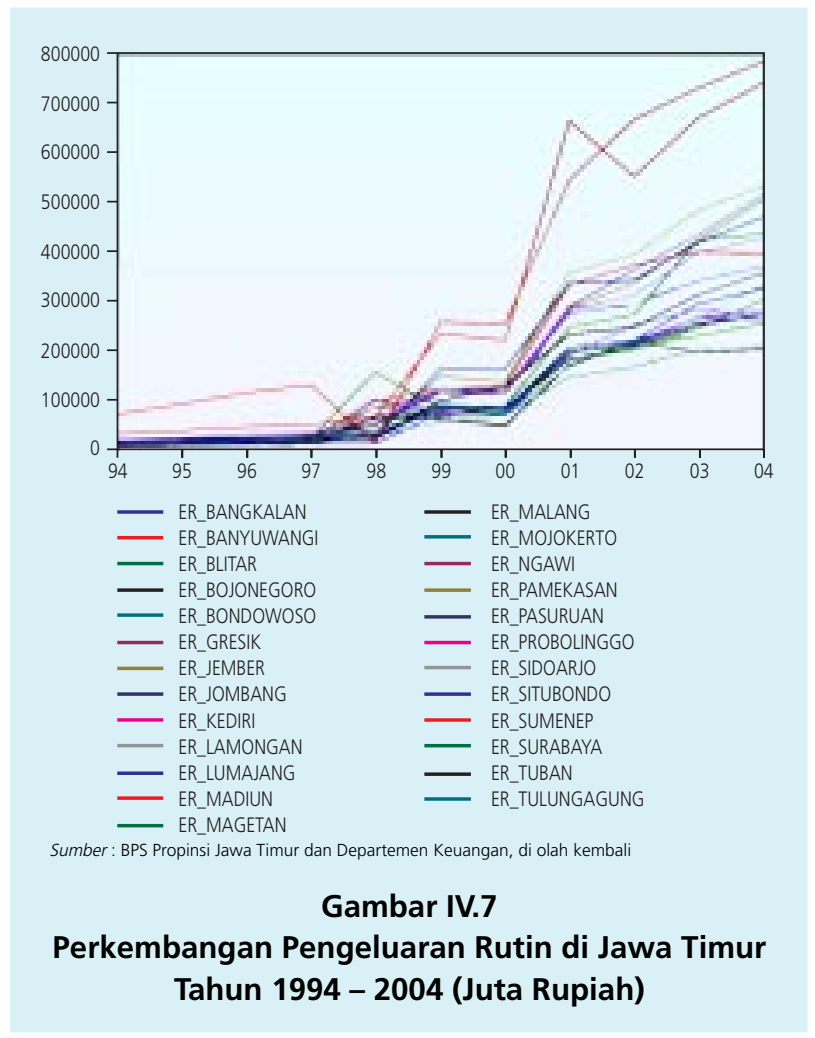

dalam arti dan kegunaan tidak jauh berbeda dengan pengeluaran rutin dalam anggaran secara nasional.

Sebagaimana terlihat dalam Gambar IV.7, pengeluaran rutin pemerintah daerah di Jawa Timur cenderung mengalamai kenaikan, terlebih setelah diberlakukannya kebijakan desentralisasi fiskal. Kebijakan desentralisasi fiskal membawa pengaruh pada naiknya pengeluaran pemerintah daerah secara terus menerus. Hal ini dikarenakan adanya kewenangan yang diberikan pemerintah daerah dalam hal pengelolaan keuangannya, seperti dalam Undang-Undang Nomor 22 tahun 1999 yang kemudian di revisi dengan Undang-Undang Nomor 32 tahun 2004 tentang Pemerintahan Daerah dan Undang-Undang Nomor 25 tahun 1999 yang kemudian juga di revisi dengan Undang-Undang Nomor 33 tahun 2004 tentang Perimbangan Keuangan PusatDaerah. Kedua Undang-Undang inilah yang memberikan keleluasaan kepada pemerintah daerah untuk meningkatkan atau menurunkan pengeluarannya sesuai dengan kebutuhannya.

Indikator berikutnya adalah jumlah dan komposisi pengeluaran pembangunan daerah. Sejalan dengan pelaksanaan kebijakan otonomi daerah, tiap-tiap daerah diberikan hak dan keleluasaan yang sama dalam mengelola daerahnya sesuai dengan potensi yang dimilikinya demi mencapai kesejahteraan masyarakat. Salah satu hal yang ditujukan untuk mencapai 


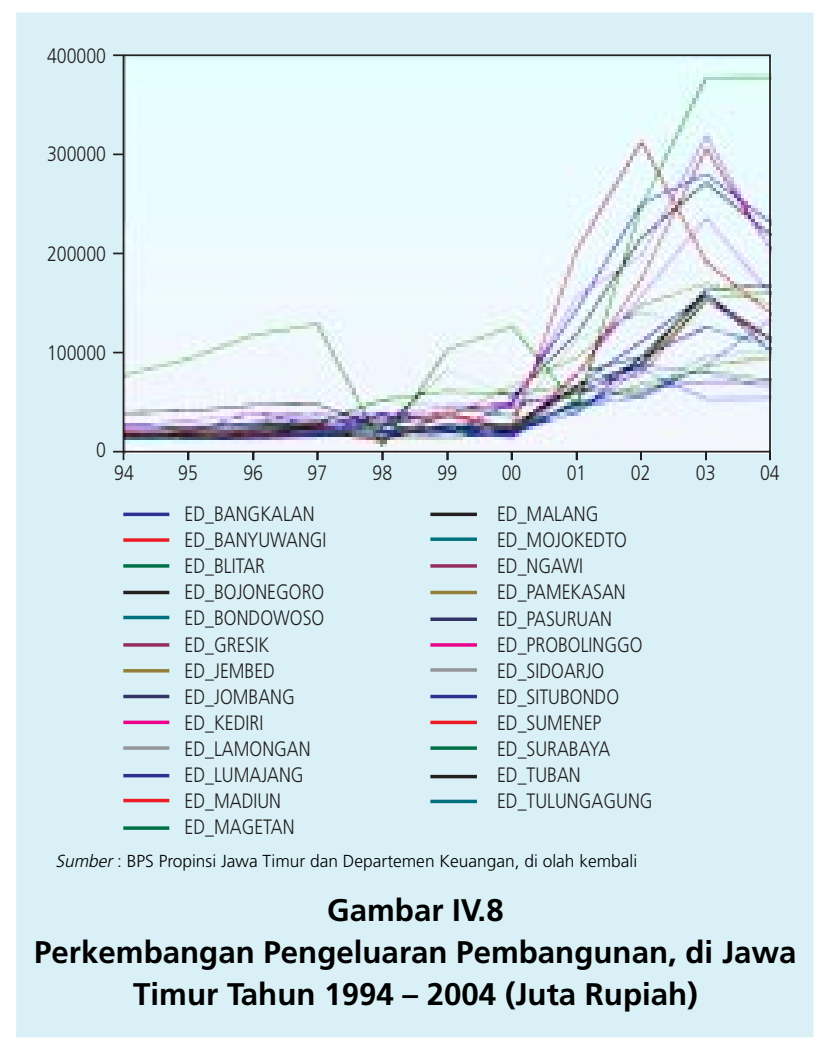

kesejahteraan masyarakat ialah langkah pembangunan daerah. Pembangunan daerah di sektor publik dilakukan oleh daerah sesuai dengan kewenangan dan kemampuannya. Kewenangan tersebut membawa implikasi pada besar kecilnya dana yang di alokasikan untuk pembangunan.

Dari iluatrasi Gambar 4.8. terlihat bahwa pola pertumbuhan pengeluaran pembangunan di tiap-tiap daerah penelitian memiliki arah pergerakan yang sama. Pada masa krisis ekonomi 1997 - 1999 pertumbuhan pengeluaran pembangunan lebih fluktuatif dan memiliki kecenderungan yang menurun. Hal ini lebih disebabkan oleh kemunduran perekonomian secara nasional yang memiliki implikasi juga pada kemunduran perekonomian di tiap-tiap daerah.

Sejak diberlakukannya kebijakan otonomi daerah, masing-masing daerah mencerminkan kecenderungan pertumbuhan pengeluaran pembangunan dalam APBD yang semakin naik. Hal ini salah satunya disebabkan oleh kebijakan otonomi daerah yang direspon dengan semakin giatnya daerah-daerah dalam memajukan daerahnya sesuai dengan potensi yang dimilikinya. Hal ini juga dimungkinkan dikarenakan oleh pertumbuhan ekonomi nasional yang semakin membaik pasca krisis ekonomi. Kedua hal tersebut membawa imlikasi pada perkembangan pengeluaran pembangunan yang semakin meningkat daripada periode-periode sebelumnya. 


\section{IV.2. Hasil Estimasi Model}

\section{IV.2.1. Keseluruhan Periode Penelitian (1995 - 2004)}

Untuk melihat seberapa besar pengaruh seluruh variabel independen terhadap variabel dependen pertama kali dilakukan regresi menggunakan teknik panel dengan dummy variabel pada keseluruhan periode penelitian. Hal ini dimaksudkan untuk melihat pengaruh kebijakan moneter dan kebijakan fiskal terhadap stabilitas harga dan pertumbuhan ekonomi regional di Jawa Timur dengan memasukkan shock ekonomi dan perubahan kebijakan ekonomi selama periode penelitian.

Dimasukkannya dummy variabel berupa krisis ekonomi dan kebijakan otonomi daerah adalah untuk tujuan mengakomodasi permasalahan fluktuasi data yang tajam. Dalam artian shock ekonomi dan perubahan kebijakan terjadi selama periode penelitian, sehingga dimungkinkannya perbedaan yang mendasar pada perekonomian tiap-tiap daerah antara periode sebelum dengan periode sesudah adanya shock ekonomi dan perubahan kebijakan.

Adapun hasil pengolahan data dengan keseluruhan peride dalam penelitian dapat dilihat dalam Tabel IV.2.

\begin{tabular}{|c|c|c|c|c|c|c|}
\hline \multirow{3}{*}{ Variable } & \multicolumn{6}{|c|}{$\begin{array}{l}\text { Tabel IV.2 } \\
\text { Data Panel dengan Dummy Variabel terhadap } \\
\text { Periode Penelitian (1995 - 2004) }\end{array}$} \\
\hline & \multicolumn{3}{|l|}{ PDRB } & \multicolumn{3}{|l|}{ INFLASI } \\
\hline & Coefficient & t-Statistic & Prob. & Coefficient & t-Statistic & Prob. \\
\hline GPAD? & 0.0048 & $4.1814^{*}$ & 0.0000 & -0.0057 & $-2.7725^{*}$ & 0.0060 \\
\hline GER? & 0.0000 & 0.1204 & 0.9043 & -0.0002 & -0.3303 & 0.7415 \\
\hline GED? & -0.0012 & -0.4651 & 0.6423 & 0.0101 & $2.2095 * *$ & 0.0282 \\
\hline GDPK? & -0.0124 & $-2.4070 * *$ & 0.0169 & 0.0472 & $5.1448^{*}$ & 0.0000 \\
\hline GKREDIT? & -0.0016 & -0.3776 & 0.7061 & 0.0062 & 0.8307 & 0.4070 \\
\hline BUNGA? & 0.2064 & $9.4589 *$ & 0.0000 & -1.2833 & $-33.129 *$ & 0.0000 \\
\hline DKRISIS? & -6.3719 & $-9.2225^{*}$ & 0.0000 & 2.3244 & $1.8951 * * *$ & 0.0594 \\
\hline DOTODA? & 4.0779 & $6.4592 *$ & 0.0000 & -6.3850 & $-5.6969 *$ & 0.0000 \\
\hline Fixed Effects & & & & & & \\
\hline _TULUNGAGUNG--C & 6.3854 & & & 15.3441 & & \\
\hline _BLITAR--C & 5.9313 & & & 14.7963 & & \\
\hline _KEDIRI--C & 7.4775 & & & 15.4580 & & \\
\hline _MALANG--C & 5.4896 & & & 15.6973 & & \\
\hline _LUMAJANG--C & 5.9987 & & & 14.4319 & & \\
\hline JEMBER--C & 5.7388 & & & 16.4278 & & \\
\hline _BANYUWANGI--C & 6.9989 & & & 16.2718 & & \\
\hline _BONDOWOSO--C & 4.0788 & & & 16.1247 & & \\
\hline
\end{tabular}




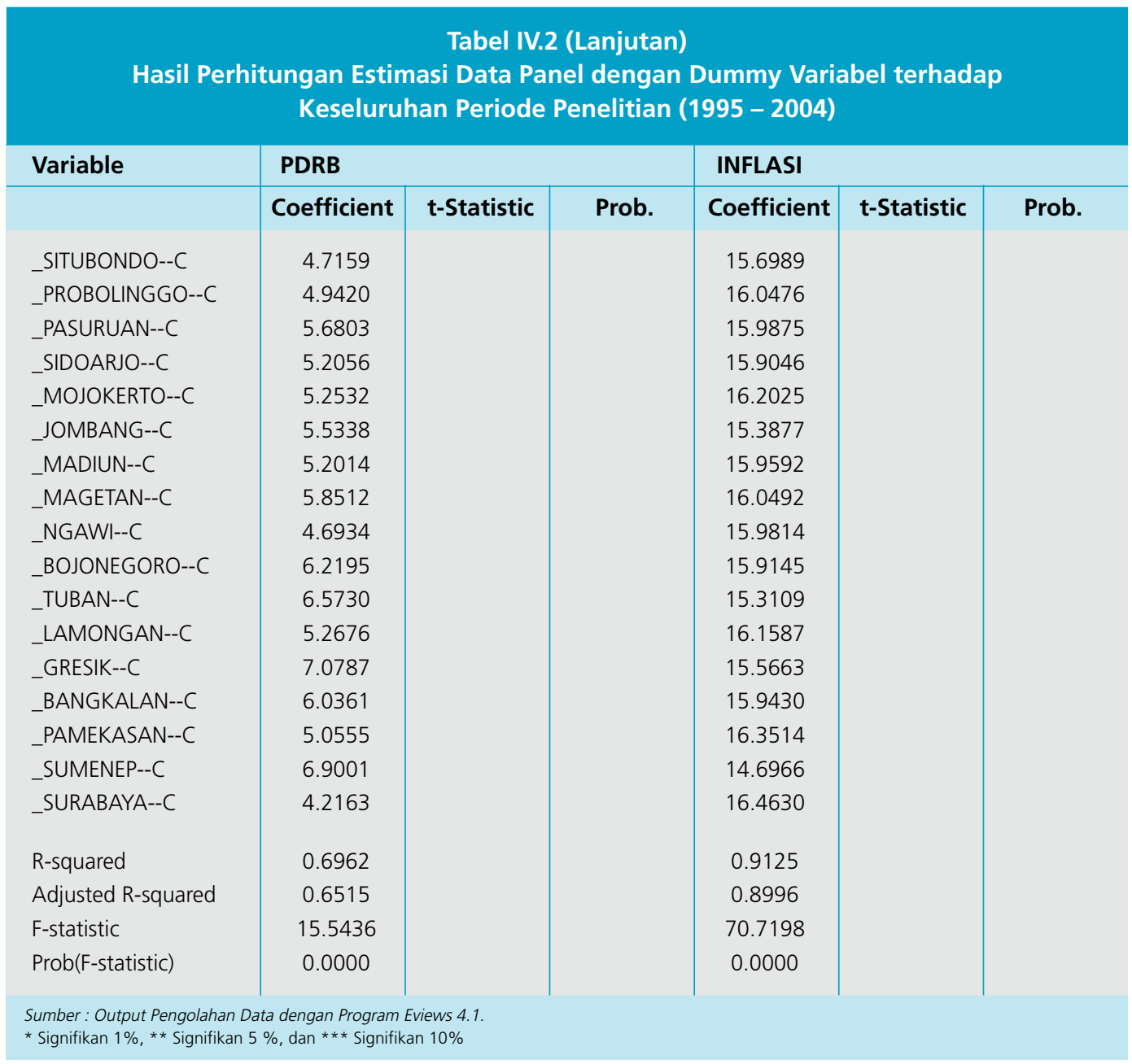

Berdasarkan hasil pengolahan data dalam tabel diatas, koefisien determinasi adalah sebesar 0,6962 untuk model pertumbuhan ekonomi dan 0,9125 untuk model inflasi, yang artinya variabel bebas dalam model mampu menjelaskan variasi dari variabel tergantung sebesar 69,62\% untuk pertumbuhan ekonomi dan 91,25\% untuk inflasi. Sedangkan sisanya dipengaruhi oleh faktor-faktor lain di luar model. Dari Tabel 4.1. untuk model pertumbuhan ekonomi menunjukkan hasil $F_{\text {hitung }}$ sebesar 15,54 dan probabilitasnya adalah sebesar 0,0000, sehingga dapat dikatakan bahwa taraf keyakinan untuk pengujian $F$ hingga $1 \%$. Dengan demikian nilai $F_{\text {hitung }}>F_{\text {tabel }}$ yang berarti HO ditolak. Demikian pula untuk model inflasi yang menunjukkan nilai F hitung sebesar 70,72 dengan probabilitasnya sebesar 0,0000, yang dapat dikatakan pula bahwa taraf keyakinan untuk pengujian $\mathrm{F}$ model inflasi hingga 1\%. Artinya, secara bersama-sama (simultan) variabel bebas dalam model mempunyai pengaruh yang signifikan terhadap variabel tergantung (inflasi dan pertumbuhan ekonomi). 
Pengaruh tiap-tiap variabel independen secara parsial terhadap pertumbuhan ekonomi juga dapat diketahui dari Tabel IV.2. Dari tabel tersebut terlihat bahwa variabel pertumbuhan pendapatan asli daerah (GPAD), dan suku bunga riil (BUNGA) secara individu berpengaruh terhadap pertumbuhan ekonomi hingga taraf keyakinan $1 \%$, sedangkan untuk pertumbuhan dana pihak ketiga (GDPK) berpengaruh terhadap pertumbuhan ekonomi hingga taraf keyakinan $5 \%$. Dengan demikian $\mathrm{H}_{0}$ di tolak, artinya variabel GPAD, GDPK, dan BUNGA secara individu berpengaruh terhadap pertumbuhan ekonomi. Sedangkan tidak signifikannya variabel pengeluaran rutin (GER), pengeluaran pembangunan (GED) dan kredit dapat diartikan pula bahwa variabel-variabel tersebut tidak memiliki pengaruh yang signifikan terhadap pertumbuhan ekonomi. Dari Tabel IV.2. diatas dapat diketahui bahwa secara individu variabel pertumbuhan pendapatan asli daerah (GPAD), pertumbuhan dana pihak ketiga (GDPK) dan suku bunga riil (BUNGA) secara individu berpengaruh terhadap inflasi dalam taraf signifikansi $1 \%$, sedangkan untuk variabel pengeluaran pembangunan (ED), berpengaruh signifikan hingga taraf signifikansi $5 \%$. Dengan demikian $\mathrm{H}_{0}$ di tolak, atau dapat diartikan bahwa variabel GPAD, GDPK, BUNGA dan GED secara individu berpengaruh terhadap Inflasi. Sedangkan untuk variabel pertumbuhan pengeluaran rutin (GER) dan kredit tidak memiliki pengaruh yang signifikan terhadap inflasi regional di Jawa Timur.

Nilai t-hitung variabel dummy dalam regresi data panel menunjukkan angka yang signifikan, baik alam model pertumbuhan ekonomi maupun model inflasi. Signifikannya nilai thitung dari variabel dummy tersebut menunjukkan bahwa selama periode penelitian shock ekonomi dan perubahan kebijakan membawa pengaruh yang signifikan terhadap variasi pertumbuhan ekonomi dan inflasi regional di Jawa Timur.

\section{IV.2.2. Periode Sebelum Krisis (1995 - 1997)}

Pada bagian ini analisis di fokuskan pada periode sebelum terjadinya shock ekonomi. Adapun hasil perhitungan estimasi pada periode sebelum krisis adalah sebagai berikut :

Tabel IV.3

Hasil Perhitungan Estimasi dengan Data Panel pada Periode Sebelum Krisis (1995 - 1997)

\begin{tabular}{l|c|c|c|c|c|c|} 
Variable & \multicolumn{2}{l|}{ PDRB } & \multicolumn{2}{l}{ INFLASI } \\
\hline & Coefficient & t-Statistic & Prob. & Coefficient & t-Statistic & Prob. \\
GPAD? & 0.0129 & 0.6504 & 0.5188 & -0.0627 & $-1.9673^{* * *}$ & 0.0555 \\
GER? & 0.0002 & 0.6090 & 0.5457 & -0.0003 & -0.6592 & 0.5132 \\
GED? & -0.0079 & -0.4810 & 0.6329 & 0.0583 & $2.1948 * *$ & 0.0335 \\
GDPK? & 0.0903 & $2.8518^{*}$ & 0.0066 & -0.0958 & $-1.8779 * * *$ & 0.0670
\end{tabular}




\begin{tabular}{|c|c|c|c|c|c|c|}
\hline \multirow[t]{2}{*}{ Variable } & \multicolumn{3}{|l|}{ PDRB } & \multicolumn{3}{|l|}{ INFLASI } \\
\hline & Coefficient & t-Statistic & Prob. & Coefficient & t-Statistic & Prob. \\
\hline GKREDIT? & -0.0303 & -0.9968 & 0.3243 & 0.0884 & $1.8046^{* * *}$ & 0.0780 \\
\hline BUNGA? & 0.1061 & $1.7065 * * *$ & 0.0950 & -0.8245 & $-8.2307^{*}$ & 0.0000 \\
\hline Fixed Effects & & & & & & \\
\hline _TULUNGAGUNG--C & 4.5071 & & & 15.2790 & & \\
\hline _BLITAR--C & 1.6975 & & & 15.8318 & & \\
\hline _KEDIRI--C & 7.8151 & & & 17.0681 & & \\
\hline _MALANG--C & 4.0688 & & & 15.2005 & & \\
\hline _LUMAJANG--C & 3.4938 & & & 15.5033 & & \\
\hline _JEMBER--C & 4.0153 & & & 16.9370 & & \\
\hline _BANYUWANGI--C & 5.3308 & & & 11.4235 & & \\
\hline _BONDOWOSO--C & 2.6290 & & & 15.5207 & & \\
\hline _SITUBONDO--C & 4.2701 & & & 13.8157 & & \\
\hline _PROBOLINGGO--C & 3.2328 & & & 14.9127 & & \\
\hline _PASURUAN--C & 4.9173 & & & 17.3653 & & \\
\hline _SIDOARJO--C & 4.7313 & & & 14.9017 & & \\
\hline _MOJOKERTO--C & 3.2284 & & & 15.5643 & & \\
\hline _JOMBANG--C & 2.6664 & & & 16.3663 & & \\
\hline _MADIUN--C & 3.3628 & & & 14.1841 & & \\
\hline _MAGETAN--C & 3.0419 & & & 14.4873 & & \\
\hline _NGAWI--C & 2.7770 & & & 16.4602 & & \\
\hline _BOJONEGORO--C & 4.2639 & & & 14.4447 & & \\
\hline _TUBAN--C & 4.4191 & & & 15.4707 & & \\
\hline _LAMONGAN--C & 3.2197 & & & 15.0970 & & \\
\hline _GRESIK--C & 7.3058 & & & 15.1843 & & \\
\hline _BANGKALAN--C & 2.7147 & & & 14.8873 & & \\
\hline _PAMEKASAN--C & 1.9830 & & & 16.9216 & & \\
\hline _SUMENEP--C & 8.5419 & & & 13.3685 & & \\
\hline _SURABAYA--C & 7.2057 & & & 14.7501 & & \\
\hline R-squared & 0.5940 & & & 0.7371 & & \\
\hline Adjusted R-squared & 0.3172 & & & 0.5579 & & \\
\hline F-statistic & 2.1458 & & & 4.1128 & & \\
\hline Prob(F-statistic) & 0.0103 & & & 0.0000 & & \\
\hline
\end{tabular}

Seperti yang terlihat dalam Tabel IV.3. nilai koefisien determinasi $\left(R^{2}\right)$ untuk model pertumbuhan ekonomi nilai $\mathrm{R}^{2}$ adalah 0,594 dan untuk model inflasi adalah sebesar 0,7371. Hal ini dapat diartikan bahwa variabel bebas dalam model mampu menjelaskan variasi pengaruh dari variabel tergantung sebesar 59,4\% untuk pertumbuhan ekonomi dan 73,71\% untuk inflasi. Sedangkan sisanya dipengaruhi oleh faktor-faktor lain di luar model. Dari Tabel IV.3. di atas 
terlihat nilai $F_{\text {hitung }}$ adalah sebesar 4,11 untuk model pertumbuhan ekonomi dan 2,14 untuk model inflasi. Hal ini secara langsung menolak hipotesis $\mathrm{H}_{0}$ atau dengan kata lain, secara bersamasama variabel-variabel kebijakan moneter dan variabel kebijakan fiskal mempengaruhi pertumbuhan ekonomi dan inflasi hingga taraf signifikansi $1 \%$, dimana probabilitas $\mathrm{F}_{\text {hitung }}$ masing-masing model adalah 0,0103 dan 0,0000.

Dari Tabel IV.3. telihat hanya variabel pertumbuhan dana pihak ketiga (GDPK), dan bunga yang berpengaruh secara individu terhadap pertumbuhan ekonomi di 25 daerah penelitian dengan taraf signifikansi masing-masing $1 \%$ dan 10\%. Sedangkan untuk variabel pertumbuhan pendapatan asli daerah (GPAD), pertumbuhan pengeluaran rutin (GER), pertumbuhan pengeluaran pembangunan (GED), dan pertumbuhan kredit (GKREDIT) secara individu tidak berpengaruh secara signifikan terhadap pertumbuhan ekonomi di 25 daerah penelitian selama periode sebelum krisis (1995 -1997). Sebagaimana yang terdapat dalam Tabel IV.3. di atas, variabel pertumbuhan pendapatan asli daerah (GPAD), pengeluaran pembangunan (GED), dana pihak ketiga (GDPK), kredit perbankan di daerah (GKREDIT) dan suku bunga riil (BUNGA) masingmasing berpengaruh secara individu terhadap inflasi, meskipun taraf signifikansinya berbedabeda. Hanya pertumbuhan pengeluaran rutin (GER) yang tidak berpengaruh secara signifikan terhadap perubahan inflasi selama periode sebelum krisis.

Selama periode sebelum krisis ekonomi (1995 - 1997), pertumbuhan ekonomi regional di Jawa Timur hanya signifikan dipengaruhi oleh kebijakan moneter, yaitu pertumbuhan DPK dan suku bunga riil. Pertumbuhan DPK dan suku bunga memiliki pengaruh yang positif terhadap pertumbuhan ekonomi. Setiap kenaikan 1\% dana yang dihimpun perbankan di daerah, menyebabkan kenaikan pertumbuhan ekonomi sebesar 0,09\%. Sedangkan setiap kenaikan $1 \%$ suku bunga menyebabkan kenaikan pertumbuhan ekonomi sebesar 0,11\%. Hal ini merupakan keterbalikan dengan teori, dimana secara teoritis setiap kenaikan suku bunga cenderung menurunkan investasi dan pada akhirnya juga menurunkan pertumbuhan ekonomi.

Kebijakan moneter dan kebijakan fiskal selama periode sebelum krisis memiliki pengaruh yang lebih bervariasi terhadap inflasi daripada terhadap pertumbuhan ekonomi. Pertumbuhan PAD, pertumbuhan pengeluaran pembangunan, pertumbuhan DPK, pertumbuhan kredit dan suku bunga riil memiliki pengaruh yang signifikan terhadap inflasi regional di Jawa Timur. Pertumbuhan PAD, pertumbuhan DPK dan suku bunga riil memiliki pengaruh negatif (trade off) terhadap inflasi. Kenaikan pertumbuhan PAD pada periode krisis cenderung menurunkan inflasi, demikian pula dengan naiknya pertumbuhan DPK dan suku bunga yang cenderung menurunkan inflasi. Naiknya suku bunga secara teoritis menurunkan inflasi, hal ini dikarenakan jumlah uang yang beredar dimasyarakat cenderung turun, masyarakat lebih memilih untuk menabung daripada membelanjakan uang, meskipun secara riil suku bunga lebih rendah 
daripada laju inflasi. Setiap kenaikan PAD, DPK, dan bunga sebesar 1\%, menyebabkan inflasi turun masing-masing sebesar 0,06\%, 0,096\%, dan 0,82\%. Sedangkan pertumbuhan pengeluaran pembangunan, dan kredit memiliki pengaruh positif (komplemen) terhadap inflasi regional. Setiap kenaikan pengeluaran pembangunan dan kredit sebesar $1 \%$, menyebabkan inflasi naik masing-masing sebesar 0,06\% dan 0,09\%.

\section{IV.2.3. Periode Krisis (1998 - 2004)}

Sebagaimana yang telah dijelaskan pada bagian-bagian sebelumnya, bahwa anilisis selama periode shock ekonomi dilakukan pembedaan. Pada bagian ini analisis di fokuskan pada periode krisis ekonomi (1998 - 2004), yang tentunya jelas memiliki perbedaan yang mendasar dengan bagian-bagian analisis sebelumnya.

\begin{tabular}{l} 
Hasil Perhitungan Estimasi dengan Data Panel pada Periode Krisis (1998 - 2004) \\
Variable \\
\hline
\end{tabular}




\begin{tabular}{|c|c|c|c|c|c|c|}
\hline \multirow[t]{2}{*}{ Variable } & \multicolumn{3}{|l|}{ PDRB } & \multicolumn{3}{|l|}{ INFLASI } \\
\hline & Coefficient & t-Statistic & Prob. & Coefficient & t-Statistic & Prob. \\
\hline _BOJONEGORO--C & 3.8150 & & & 12.3046 & & \\
\hline _TUBAN--C & 3.1198 & & & 12.7224 & & \\
\hline _LAMONGAN--C & 2.4598 & & & 13.1739 & & \\
\hline _GRESIK--C & 3.3453 & & & 12.6526 & & \\
\hline _BANGKALAN--C & 3.5577 & & & 13.5731 & & \\
\hline _PAMEKASAN--C & 2.0973 & & & 13.6649 & & \\
\hline _SUMENEP--C & 2.3782 & & & 12.2642 & & \\
\hline _SURABAYA--C & -0.9734 & & & 14.1788 & & \\
\hline R-squared & 0.6476 & & & 0.9256 & & \\
\hline Adjusted R-squared & 0.5742 & & & 0.9101 & & \\
\hline F-statistic & 8.8203 & & & 59.7081 & & \\
\hline Prob(F-statistic) & 0.0000 & & & 0.0000 & & \\
\hline
\end{tabular}

Seperti yang terlihat dalam Tabel IV.4. nilai koefisien determinasi $\left(R^{2}\right)$ untuk model pertumbuhan ekonomi adalah sebesar 0,6476 dan untuk model inflasi nilai $\mathrm{R}^{2}$ adalah 0,9256. Hal ini dapat diartikan bahwa variabel bebas dalam model mampu menjelaskan variasi pengaruh dari variabel tergantung sebesar 64,76\% untuk pertumbuhan ekonomi dan 92,56\% untuk model inflasi. Sedangkan sisanya dipengaruhi oleh faktor-faktor lain di luar model. Nilai $F_{\text {hitung }}$ dalam Tabel IV.4. adalah sebesar 8,82 untuk model pertumbuhan ekonomi dan 59,71 untuk model inflasi. Hal ini secara langsung menunjukkan bahwa $F_{o}\left(F_{\text {observasi }}\right)>F_{t}\left(F_{\text {tabel }}\right)$, dimana hipotesis $\mathrm{H}_{0}$ berada dalam daerah penolakan. Dengan kata lain bahwa secara bersama-sama variabel kebijakan moneter dan variabel kebijakan fiskal mempengaruhi inflasi dan pertumbuhan ekonomi hingga taraf signifikansi $1 \%$, dimana probabilitas $\mathrm{F}_{\text {hitung }}$ masing-masing adalah 0,0000.

Dari Tabel 4.3. dapat diketahui variabel yang berpengaruh signifikan secara parsial terhadap pertumbuhan ekonomi selama periode krisis. Variabel pertumbuhan pendapatan asli daerah (GPAD), dana pihak ketiga (GDPK), dan suku bunga riil (BUNGA) berpengaruh secara signifikan dalam taraf signifikansi $1 \%$, sedangkan variabel pertumbuhan pengeluaran rutin (GER) berpengaruh signifikansi hingga taraf 5\%. Untuk variabel pertumbuhan kredit (GKREDIT) dan pengeluaran pembangunan (GED) tidak memiliki pengaruh yang signifikan terhadap pertumbuhan ekonomi. Dapat disimpulkan bahwa hanya pertumbuhan PAD, GER, GDPK, dan suku bunga riil yang signifikan secara individu dalam mempengaruhi pertumbuhan ekonomi selam periode krisis ekonomi. 
Pertumbuhan PAD dan suku bunga memiliki pengaruh positif terhadap pertumbuhan ekonomi. Setiap kenaikan PAD dan suku bunga sebesar 1\%, menyebabkan petumbuhan ekonomi masing-masing sebesar 0,006\% dan 0,27\%. Sedangkan pertumbuhan pengeluaran rutin, pertumbuhan dana pihak ketiga memiliki pengaruh negatif (trade off) terhadap pertumbuhan ekonomi. Selama periode krisis tingginya suku bunga secara nominal mendorong masyarakat menyelamatkan uangnya dengan menyimpan di bank. akan tetapi dengan prinsip kehati-hatian, perbankan cenderung berhati-hati dalam menyalurkan kredit, sehingga pertumbuhan DPK trade off dengan pertumbuhan ekonomi. Demikian pula dengan pertumbuhan pengeluaran rutin selama periode krisis yang memiliki hubungan negatif dengan pertumbuhan ekonomi, menujukkan bahwa pengeluaran rutin yang cenderung tinggi pada masa tersebut setidaknya meningkatkan daya beli masyarakat, meskipun pada dasarnya secara riil daya beli masyarakat turun akibat inflasi yang tinggi. Setiap kenaikan pengeluaran rutin dan dana pihak ketiga masing masing sebesar $1 \%$ menyebabkan turunnya pertumbuhan ekonomi masing-masing sebesar $0,007 \%$ dan $0,016 \%$.

Variabel pertumbuhan pendapatan asli daerah (GPAD), pengeluaran rutin (GER), dana pihak ketiga (GDPK) dan suku bunga riil (BUNGA) memiliki pengaruh signifikan terhadap inflasi regional dengan taraf signifikansi $1 \%$. Sedangkan untuk variabel pengeluaran pembangunan (GED) dan kredit tidak berpengaruh secara signifikan terhadap inflasi. Dengan demikian dapat diartikan bahwa selama periode setelah krisis ekonomi hanya GPAD, GER, GDPK, dan BUNGA yang secara individu berpengaruh signifikan terhadap inflasi regional di Jawa Timur.

Selama periode krisis, variabel pertumbuhan pengeluaran rutin, dan pertumbuhan DPK memiliki pengaruh positif terhadap inflasi. Naiknya pengeluaran rutin cenderung mendorong naiknya agregat demand, sehingga kenaikan aggregat demand tersebut membawa implikasi pada laju inflasi yang juga naik (Demand Pull Inflation). Sedangkan pertumbuhan DPK berpengaruh positif terhadap inflasi, menunjukkan bahwa naiknya DPK yang masuk perbankan menurunkan jumlah uang beredar yang ada di masyarakat. Setiap kenaikan pengeluaran rutin dan DPK masingmasing sebesar 1\%, menyebabkan inflasi naik sebesar 0,02\% dan 0,04\%. Sedangkan pertumbuhan PAD dan suku bunga trade off dengan inflasi regional. Selama periode krisis naiknya PAD menurunkan inflasi, hal ini dikarenakan inflasi yang terjadi pada periode tersebut adalah inflasi dari sisi permintaan. Sedangkan naiknya suku bunga efektif mempengaruhi inflasi, sesuai dengan teori bahwa setiap kenaikan suku bunga akan menurunkan laju inflasi. Setiap kenaikan PAD dan suku bunga sebesar 1\%, menyebabkan turunnya inflasi sebaesar 0,01\% dan 1,41\%.

\section{IV.2.4. Periode Sebelum Otonomi Daerah (1994 - 1999)}

Sebagaimana hasil regresi panel data dengan variabel dummy shock ekonomi yang berpengaruh signifikan terhadap pertumbuhan ekonomi dan inflasi, dalam regresi awal 
(keseluruhan periode), kebijakan otonomi daerah juga signifikan berpengaruh terhadap pertumbuhan ekonomi dan inflasi regional di Jawa Timur. Sehingga dalam bagian ini dan bagian berikutnya analisis difokuskan untuk menganalisis periode sebelum dan sesudah penerapan kebijakan desentralisasi fiskal (otonomi daerah). Pembagian ini penting dilakukan untuk mengetahui pola perilaku dan fenomena inflasi dan pertumbuhan ekonomi sebelum dan setelah penerapan kebijakan otonomi daerah.

Di bawah ini adalah tabel hasil perhitungan estimasi yang dilakukan terhadap data sebelum penerapan kebijakan desentralisasi fiskal (otonomi daerah).

\begin{tabular}{|c|c|c|c|c|c|c|}
\hline \multirow{3}{*}{ Variable } & \multicolumn{5}{|c|}{$\begin{array}{c}\text { Tabel IV.5 } \\
\text { Hasil Perhitungan Estimasi dengan Data Panel } \\
\text { Periode Sebelum Otonomi Daerah (1995 - 1999) }\end{array}$} & \\
\hline & \multicolumn{3}{|l|}{ PDRB } & \multicolumn{3}{|l|}{ INFLASI } \\
\hline & Coefficient & t-Statistic & Prob. & Coefficient & t-Statistic & Prob. \\
\hline GPAD? & 0.0026 & 0.7646 & 0.4464 & -0.0043 & -0.9742 & 0.3325 \\
\hline GER? & 0.0002 & 0.3848 & 0.7012 & -0.0003 & -0.5916 & 0.5555 \\
\hline GED? & 0.0045 & 0.5006 & 0.6178 & 0.0040 & 0.3480 & 0.7286 \\
\hline GDPK? & -0.0425 & $-2.5437 *$ & 0.0126 & 0.1340 & $6.2898^{*}$ & 0.0000 \\
\hline GKREDIT? & 0.0092 & 0.7133 & 0.4774 & -0.0355 & $-2.1684 * *$ & 0.0326 \\
\hline BUNGA? & 0.3001 & $8.6288^{*}$ & 0.0000 & -1.2607 & $-28.418^{*}$ & 0.0000 \\
\hline Fixed Effects & & & & & & \\
\hline TULUNGAGUNG--C & 3.8053 & & & 13.2218 & & \\
\hline _BLITAR--C & 4.4253 & & & 12.8207 & & \\
\hline _KEDIRI--C & 7.7062 & & & 12.7723 & & \\
\hline _MALANG--C & 4.6179 & & & 13.2101 & & \\
\hline _LUMAJANG--C & 3.846 & & & 14.358 & & \\
\hline _JEMBER--C & 4.2242 & & & 14.3981 & & \\
\hline _BANYUWANGI--C & 5.3578 & & & 13.4737 & & \\
\hline _BONDOWOSO--C & 1.8493 & & & 16.7721 & & \\
\hline _SITUBONDO--C & 2.575 & & & 16.0453 & & \\
\hline _PROBOLINGGO--C & 3.9893 & & & 13.8983 & & \\
\hline _PASURUAN--C & 4.3017 & & & 13.7229 & & \\
\hline _SIDOARJO--C & 3.3904 & & & 14.1572 & & \\
\hline _MOJOKERTO--C & 3.0074 & & & 14.5817 & & \\
\hline _JOMBANG--C & 3.4167 & & & 12.4011 & & \\
\hline _MADIUN--C & 3.5108 & & & 14.5216 & & \\
\hline _MAGETAN--C & 3.1082 & & & 15.3216 & & \\
\hline _NGAWI--C & 3.1327 & & & 15.197 & & \\
\hline _BOJONEGORO--C & 3.2526 & & & 15.6528 & & \\
\hline _TUBAN--C & 6.1838 & & & 13.5693 & & \\
\hline _LAMONGAN--C & 4.1531 & & & 15.0504 & & \\
\hline _GRESIK--C & 6.2866 & & & 11.7901 & & \\
\hline
\end{tabular}




\begin{tabular}{|c|c|c|c|c|c|c|}
\hline \multirow{3}{*}{ Variable } & \multicolumn{5}{|c|}{$\begin{array}{l}\text { Tabel IV.5 (Lanjutan) } \\
\text { Hasil Perhitungan Estimasi dengan Data Panel } \\
\text { Periode Sebelum Otonomi Daerah (1995 - 1999) }\end{array}$} & \\
\hline & \multicolumn{3}{|l|}{ PDRB } & \multicolumn{3}{|l|}{ INFLASI } \\
\hline & Coefficient & t-Statistic & Prob. & Coefficient & t-Statistic & Prob. \\
\hline _BANGKALAN--C & 4.4522 & & & 13.9262 & & \\
\hline _PAMEKASAN--C & 2.6131 & & & 15.5389 & & \\
\hline _SUMENEP--C & 9.0081 & & & 13.5488 & & \\
\hline _SURABAYA--C & 1.3213 & & & 16.2585 & & \\
\hline R-squared & 0.6918 & & & 0.9526 & & \\
\hline Adjusted R-squared & 0.5934 & & & 0.9375 & & \\
\hline F-statistic & 7.0332 & & & 62.9497 & & \\
\hline Prob(F-statistic) & 0.0000 & & & 0.0000 & & \\
\hline
\end{tabular}

Dari Tabel IV.5 dapat dilihat bahwa nilai $\mathrm{R}^{2}$ dari model pertumbuhan ekonomi adalah sebesar 0,6918 dan untuk model inflasi adalah 0,9526. Hal ini dapat diartikan bahwa variabel bebas dalam model mampu menjelaskan variasi pengaruh dari variabel tergantung sebesar 69,18\% untuk pertumbuhan ekonomi dan 95,26\% untuk inflasi. Sedangkan sisanya dipengaruhi oleh faktor-faktor lain di luar model.

Nilai $F_{\text {hitung }}$ dari tabel diatas menunjukkan bahwa untuk model pertumbuhan ekonomi nilai $F_{\text {hitung }}$ adalah sebesar 7,033 dan untuk model inflasi nilai $F_{\text {hitung }}$ adalah sebesar 62,9497. Hal ini secara langsung menunjukkan bahwa $F_{0}\left(F_{\text {observas }}\right)>F_{t}\left(F_{\text {tabee }}\right)$, dimana hipotesis $H_{0}$ berada dalam daerah penolakan. Selama periode sebelum penerapan kebijakan otonomi daerah variabel kebijakan moneter dan variabel kebijakan fiskal secara bersama-sama mempengaruhi pertumbuhan ekonomi dan inflasi hingga taraf signifikansi $1 \%$, dimana probabilitas $F_{\text {hitung }}$ masing-masing model adalah 0,0000.

Selama periode sebelum otonomi daerah hanya variabel moneter (GDPK dan BUNGA) yang secara individu mempengaruhi pertumbuhan ekonomi. Hal tersebut ditunjukkan dengan signifikannya nilai t statistik hingga taraf signifikansi sebesar $1 \%$, adapun variabel kebijakan fiskal (GPAD, GER dan GED) dan variabel moneter berupa kredit secara individu tidak memiliki pengaruh yang signifikan dalam mempengaruhi inflasi. Hal ini dapat diartikan bahwa hanya variabel moneter berupa BUNGA dan GDPK yang memiliki pengaruh cukup berarti terhadap variasi inflasi yang terjadi di daerah penelitian.

Sebelum diterapkannya kebijakan otonomi daerah, pertumbuhan DPK trade off dengan pertumbuhan ekonomi. Setiap kenaikan dana yang dihimpun oleh perbankan dari masyarakat 
jika tidak diimbangi dengan naiknya jumlah kredit, cenderung menurunkan pertumbuhan ekonomi. Setiap kenaikan DPK sebesar 1\%, pertumbuhan ekonomi akan turun sebesar 0,045, dengan asumsi variabel-variabel lainnya adalah konstan. Sedangkan pada periode yang sama, suku bunga riil memiliki pengaruh positif terhadap pertumbuhan ekonomi. Pada periode 1997 - 2000 suku bunga riil pada dasarnya adalah minus, sehingga jika pelaku ekonomi mengetahui hal ini, kredit masih juga tetap dilakukan mengingat spread suku bunga dengan inflasi masih tinggi. Setiap kenaikan suku bunga sebesar $1 \%$, menyebabkan pertumbuhan ekonomi naik sebesar $0,03 \%$.

Berbeda dengan variabel-variabel yang mempengaruhi pertumbuhan ekonomi, secara individu variabel-variabel yang signifikan mempengaruhi inflasi diantaranya adalah pertumbuhan DPK (GDPK), suku bunga riil (BUNGA) dan pertumbuhan kredit (GKREDIT). Hal tersebut ditunjukkan oleh signifikannya nilai t statistik hingga taraf keyakinan untuk masing-masing variabel tersebut sebesar $1 \%$ dan 5\%. Dengan demikian selama periode sebelum penerapan otonomi daerah hanya variabel moneter (GDPK, GKREDIT dan BUNGA) yang lebih menentukan variasi inflasi yang terjadi di daerah penelitian.

Variabel pertumbuhan DPK memiliki pengaruh positif terhadap inflasi. Naiknya dana yang dihimpun oleh perbankan didaerah cenderung mengurangi JUB yang ada di masyarakat, sehingga inflasi juga mengalami penurunan. Setiap kenaikan DPK sebesar $1 \%$, menyebabkan inflasi naik sebesar 0,13\%. Sedangkan pertumbuhan kredit dan suku bunga trade off dengan inflasi regional di Jawa Timur. Suku bunga efektif dalam menurunkan laju inflasi. Setiap kenaikan kredit dan suku bunga sebesar 1\%, menyebabkan turunnya inflasi sebesar 0,04\% dan 1,26\%.

\section{IV.2.5. Periode Otonomi Daerah (2000 - 2004)}

Dalam bagian ini analisis difokuskan untuk menganalisis periode penerapan kebijakan desentralisasi fiskal atau yang sering juga disebut otonomi daerah. Pembagian ini dirasa penting untuk mengetahui pola perilaku dan fenomena inflasi dan pertumbuhan ekonomi pada periode penerapan kebijakan desentralisasi. Dimana pada periode ini daerah diberikan kewenangan penuh dalam mengelola keuangan daerah sesuai dengan Undang-Undang Nomor 22 tahun 1999 yang kemudian di revisi dengan Undang-Undang Nomor 32 tahun 2004 tentang Pemerintahan Daerah dan Undang-Undang Nomor 25 tahun 1999 yang kemudian juga di revisi dengan Undang-Undang Nomor 33 tahun 2004 tentang Perimbangan Keuangan PusatDaerah.

Di bawah ini adalah tabel hasil perhitungan estimasi yang dilakukan terhadap data setelah penerapan kebijakan desentralisasi fiskal (2000 - 2004). 
Tabel IV.6

Hasil Perhitungan Estimasi dengan Data Panel pada Periode Otonomi Daerah (2000 - 2004)

\begin{tabular}{|c|c|c|c|c|c|c|}
\hline \multirow[t]{2}{*}{ Variable } & \multicolumn{3}{|l|}{ PDRB } & \multicolumn{3}{|l|}{ INFLASI } \\
\hline & Coefficient & t-Statistic & Prob. & Coefficient & t-Statistic & Prob. \\
\hline GPAD? & -0.0002 & -0.0699 & 0.9445 & 0.0005 & 0.1004 & 0.9203 \\
\hline GER? & 0.0021 & 0.4807 & 0.6319 & 0.0232 & $3.8559 *$ & 0.0002 \\
\hline GED? & -0.0008 & -0.4007 & 0.6896 & 0.0032 & 1.1738 & 0.2434 \\
\hline GDPK? & -0.0041 & -0.9416 & 0.3488 & 0.0002 & 0.0385 & 0.9694 \\
\hline GKREDIT? & 0.0029 & 0.9083 & 0.3661 & -0.0016 & -0.3513 & 0.7261 \\
\hline BUNGA? & -0.0796 & -1.4652 & 0.1462 & -0.3520 & $-4.6078 *$ & 0.0000 \\
\hline \multicolumn{7}{|l|}{ Fixed Effects } \\
\hline _TULUNGAGUNG--C & 5.6864 & & & 10.319 & & \\
\hline _BLITAR--C & 4.2656 & & & 9.986 & & \\
\hline _KEDIRI--C & 3.4155 & & & 10.547 & & \\
\hline _MALANG--C & 3.7732 & & & 8.3771 & & \\
\hline _LUMAJANG--C & 5.1884 & & & 7.5569 & & \\
\hline _JEMBER--C & 4.152 & & & 9.1537 & & \\
\hline _BANYUWANGI--C & 6.5617 & & & 7.0777 & & \\
\hline BONDOWOSO--C & 2.9283 & & & 7.1572 & & \\
\hline _SITUBONDO--C & 2.8424 & & & 9.3348 & & \\
\hline _PROBOLINGGO--C & 3.111 & & & 8.5317 & & \\
\hline _PASURUAN--C & 4.226 & & & 8.6605 & & \\
\hline _SIDOARJO--C & 4.4681 & & & 9.2411 & & \\
\hline _MOJOKERTO--C & 3.9757 & & & 8.7548 & & \\
\hline _OMBANG--C & 5.2521 & & & 8.654 & & \\
\hline _MADIUN--C & 3.5803 & & & 8.9172 & & \\
\hline _MAGETAN--C & 5.4533 & & & 8.3706 & & \\
\hline _NGAWI--C & 2.8448 & & & 9.1202 & & \\
\hline _BOJONEGORO--C & 5.0148 & & & 10.6729 & & \\
\hline _TUBAN--C & 3.9482 & & & 8.7161 & & \\
\hline _LAMONGAN--C & 3.7 & & & 7.5758 & & \\
\hline _GRESIK--C & 5.8781 & & & 8.3925 & & \\
\hline _BANGKALAN--C & 4.8767 & & & 8.4268 & & \\
\hline _PAMEKASAN--C & 3.6541 & & & 9.6479 & & \\
\hline _SUMENEP--C & 2.6503 & & & 7.6381 & & \\
\hline _SURABAYA--C & 4.396 & & & 8.9482 & & \\
\hline R-squared & 0.317 & & & 0.4808 & & \\
\hline Adjusted R-squared & 0.0999 & & & 0.3151 & & \\
\hline F-statistic & 1.4589 & & & 2.9015 & & \\
\hline Prob(F-statistic) & 0.0872 & & & 0.0000 & & \\
\hline
\end{tabular}

Dari tabel IV.6 dapat dilihat bahwa nilai $\mathrm{R}^{2}$ dari model pertumbuhan ekonomi adalah sebesar 0,3177 dan 0,4808 untuk model inflasi. Hal ini dapat diartikan bahwa variabel bebas 
dalam model hanya mampu menjelaskan variasi pengaruh dari variabel tergantung sebesar $31,77 \%$ untuk model pertumbuhan ekonomi dan 48,08\% untuk model inflasi. Rendahnya nilai $R^{2}$ dari model pertumbuhan ekonomi dan model inflasi menunjukkan bahwa selama periode penerapan otonomi daerah variasi dari pertumbuhan ekonomi dan inflasi yang terjadi di daerah penelitian tidak hanya di tentukan oleh variabel-variabel fiskal (GPAD, GER dan GED) dan variabelvariabel moneter (GDPK, BUNGA dan GKREDIT) melainkan lebih disebabkan oleh variabelvariabel lain yang tidak dimasukkan dalam model, seperti variabel kebijakan perundangundangan daerah dan variabel peraturan-peraturan daerah, yang mana variabel-variabel tersebut secara langsung maupun tidak langsung berpengaruh terhadap ekspektasi dari pelaku ekonomi di daerah penelitian.

Demikian pula dengan nilai $F_{\text {hitung }}$ dari tabel diatas menunjukkan bahwa untuk model pertumbuhan ekonomi nilai $F_{\text {hitung }}$ adalah sebesar 1.4589 dengan probabilitasnya sebesar 0.0872 . Untuk model inflasi nilai $F_{\text {hitung }}$ adalah sebesar 2.9015 dimana probabilitas $F_{\text {hitung }}$ adalah 0,0000. $\mathrm{Hal}$ ini secara langsung menunjukkan bahwa meskipun $\mathrm{R}^{2}$ masing-masing model kecil, tetapi nilai $F_{o}\left(F_{\text {observasi }}\right)>F_{t}\left(F_{\text {tabel }}\right)$, dengan demikian hipotesis $H_{0}$ berada dalam daerah penolakan. Dengan kata lain bahwa setelah periode penerapan kebijakan otonomi daerah variabel kebijakan moneter dan variabel kebijakan fiskal secara bersama-sama masih mempengaruhi pertumbuhan ekonomi dan inflasi hingga taraf signifikansi 10\% dan $1 \%$.

Selama diterapkannya kebijakan otonomi daerah, secara individu tidak terdapat variabel yang berpengaruh signifikan terhadap pertumbuhan ekonomi di daerah penelitian. Hal tersebut ditunjukkan terlihat dari masing-masing variabel tidak signifikan dalam taraf signifikansi $1 \%$, $5 \%$ ataupun $10 \%$. Hal ini menujukkan bahwa selama periode setelah penerapan otonomi daerah masih belum terdapat kebijakan moneter dan kebijakan fiskal regional yang mampu mendorong pertumbuhan ekonomi yang signifikan di masing-masing daerah.

Secara individu variabel-variabel yang mempengaruhi inflasi regional selama diterapkannya kebijakan otonomi daerah hanya pertumbuhan pengeluaran rutin (GER) dan suku bunga riil (BUNGA), yaitu hingga taraf signifikansi $1 \%$. Sedangkan variabel-variabel lainnya tidak memiliki pengaruh yang signifikan terhadap inflasi regional di Jawa Timur.

Selama diterapkannya kebijakan otonomi daerah, variabel pertumbuhan pengeluaran rutin berpengaruh positif terhadap inflasi regional di Jawa Timur. Tingginya pengeluaran rutin yang tidak dikendalikan cenderung meningkatkan aggregat demand, sehingga secara berkelanjutan menyebabkan inflasi dari sisi permintaan (demand pull inflation). Setiap kenaikan pengeluaran rutin sebesar $1 \%$, menyebabkan naiknya inflasi sebesar 0,023\%. Sedangkan variabel suku bunga trade off dengan inflasi regional di Jawa Timur, dimana setiap kenaikan suku bunga sebesar $1 \%$ menyebabkan inflasi turun sebesar 0,35\%. Instrumen suku bunga 
memang efektif mempengaruhi laju inflasi, suku bunga mempengaruhi inflasi dengan arah yang negatif.

\section{IV.3. Pengaruh Variabel-variabel Kebijakan terhadap Inflasi di Daerah}

Dalam mempengaruhi inflasi kebijakan yang di analisis dalam penelitian ini adalah dua kebijakan penting yaitu kebijakan moneter yang sifatnya sentralistis dan kebijakan fiskal yang desentralistis terutama pada periode setelah penerapan kebijakan otonomi daerah. Secara keseluruhan periode penelitian, signifikannya variabel dummy krisis dan otonomi daerah menunjukkan bahwa terdapat perbedaan pengaruh kebijakan moneter dan kebijakan fiskal terhadap inflasi dan pertumbuhan ekonomi selama periode penelitian. Sehingga diperlukan pembedaan analisis, sesuai dengan adanya dua fenomena ekonomi tersebut. Secara umum terdapat perbedaan pengaruh tiap-tiap variabel dalam perode yang berbeda, adapun perbandingan untuk tiap-tiap periode penelitian dapat di rangkum sebagai berikut :

\section{Tabel IV.7}

Arah Hubungan Variabel-variabel Kebijakan dengan Laju Inflasi Regional di Jawa Timur

\begin{tabular}{l|l|l|l|l|l} 
& Total & Pra Krisis & Krisis & Pra Otonomi & Otonomi \\
GPAD & - & - & - & Tidak signifikan & Tidak signifikan \\
GER & Tidak signifikan & Tidak signifikan & + & Tidak signifikan & + \\
GED & + & + & Tidak signifikan & Tidak signifikan & Tidak signifikan \\
GDPK & + & - & + & Tidak signifikan \\
GKREDIT & Tidak signifikan & + & Tidak signifikan & - & Tidak signifikan \\
BUNGA & - & - & - & -
\end{tabular}

Untuk keseluruhan periode penelitian dengan tanpa membedakan periode penelitian, kebijakan moneter dan kebijakan fiskal relatif berimbang dalam mempengaruhi pertumbuhan ekonomi dan inflasi regional di Jawa Timur. Dari sisi kebijakan fiskal, PAD memeiliki pengaruh negatif terhadap laju inflasi di Jawa Timur, demikian pula dengan suku bunga. Setiap kenaikan PAD dan suku bunga membawa implikasi pada turunnya inflasi di Jawa Timur.

Disisi lain, pertumbuhan pengeluaran pembangunan dan pertumbuhan DPK memiliki pengaruh positif terhadap inflasi regional di Jawa Timur. Pengeluaran pembangunan selama periode penelitian memiliki pengaruh positif terhadap stabilitas harga dikarenakan kenaikan pengeluaran pembangunan meningkatkan agregat demand, sehingga mendorong inflasi dari sisi permintaan (cost push inflation). Demikian pula dengan kenaikan DPK yang memiliki pengaruh positif dikarenakan fungsi intermediasi yang dapat dikatakan berjalan relatif baik. 
Membaiknya fungsi intermediasi perbankan membawa pengaruh pada jumlah uang beredar di wilayah Jawa Timur yang pada akhirnya juga berimplikasi pada stabilitas harga yang berlaku di Jawa Timur.

Selama periode sebelum krisis, keseluruhan variabel moneter signifikan dalam mempengaruhi inflasi regional, sedangkan terdapat dua variabel fiskal yang signifikan dalam mempengaruhi inflasi di daerah, yaitu pertumbuhan PAD dan pertumbuhan pengeluaran pembangunan. Dalam periode sebelum krisis masing-masing kebijakan masih bersifat sentralistis ditentukan atas kewenangan pemegang kebijakan pusat. Pada masa tersebut otoritas fiskal sepenuhnya dipegang oleh departemen keuangan sedangkan ototitas fiskal dipegang oleh Bank Indonesia dengan intervensi dari pemerintah. Sehingga penyesuaian antara dua kebijakan untuk mencapai tujuan pembangunan lebih mudah dilakukan, hingga ke daerah-daerah. Secara rata-rata kebijakan moneter pada masa sebelum krisis ekonomi lebih dominan dalam mempengaruhi inflasi. Hal ini dapat dilihat dari banyaknya variabel kebijakan moneter yang mempengaruhi inflasi dibanding variabel kebijakan fiskal.

Arah hubungan antara PAD, DPK dan suku bunga riil adalah negatif (trade off) dengan inflasi. Hubungan negatif tersebut menunjukkan bahwa besarnya PAD pada masa sebelum krisis relatif menurunkan inflasi dari sisi permintaan (demand pull inflation). Sedangkan DPK cenderung menurunkan inflasi melalui penurunan jumlah uang yang beredar di masyarakat. Kebijakan suku bunga yang dilakukan Bank Indonesia efektif mempengaruhi laju inflasi, semakin dinaikkan suku bunga oleh otoritas moneter di respon oleh turunnya laju inflasi daerah-daerah di Jawa Timur.

Pertumbuhan pengeluaran pembangunan dan kredit menunjukkan arah hubungan positif dengan inflasi selama periode sebelum krisis. Pada periode ini, pengeluaran pembangunan direspon oleh naiknya inflasi regional. Hal ini menunjukkan bahwa inflasi yang terjadi adalah inflasi dari sisi permintaan akibat naiknya aggregat demand. Sedangkan pertumbuhan kredit menujukkan arah positif mendorong laju inflasi dari sisi penawaran. Semakin naik suku bunga yang berlaku atas kredit, semakin mendorong biaya yang dikeluarkan untuk investasi sehingga inflasi dari sisi penawaran (cost push inflation) terjadi pada periode ini.

Selama periode krisis ekonomi, dominasi kebijakan dalam mempengaruhi inflasi regional sedikit berbeda dengan periode sebelum krisis. Secara rata-rata, kebijakan moneter dan kebijakan fiskal relatif berimbang dalam mempengaruhi inflasi. Perbedaan tersebut dikarenakan selama periode krisis ekonomi terdapat pula periode diterapkannya kebijakan otonomi daerah, sehingga secara tidak langsung maupun secara langsung, kebijakan desentralisasi fiskal tersebut berimplikasi pada signifikannya kebijakan fiskal regional dalam mempengaruhi perekonomian di daerah. 
Pertumbuhan PAD dan suku bunga riil menunjukkan arah negatif (trade off) dengan laju inflasi pada periode krisis. Pada periode ini turunnya laju inflasi dari sisi penawaran dipengaruhi oleh pertumbuhan PAD, sedangkan laju inflasi juga turun dipengaruhi oleh suku bunga riil. Instrumen suku bunga untuk upaya mempengaruhi inflasi oleh otoritas moneter menujukkan efektifnya pemakaian instrumen ini. Arah hubungan positif dengan inflasi pada periode krisis di tunjukkan oleh pertumbuhan pengeluaran rutin dan pertumbuhan dana yang dihimpun oleh perbankan didaerah. Inflasi dari sisi permintaan didorong naik oleh pertumbuhan pengeluaran rutin, akibat naiknya aggregat demand. Aggregat demand yang diikuti dengan turunnya jumlah uang yang beredar di masyarakat juga menyebabkan inflasi.

Pada periode sebelum otonomi daerah, variabel-variabel kebijakan moneter berupa suku bunga dan kredit lebih dominan dalam mempengaruhi inflasi di daerah. Hal ini ditunjukkan oleh signifikannya nilai t statistik dari kedua variabel tersebut. Lebih dominannya kebijakan moneter dalam mempengaruhi inflasi dimungkinkan karena dalam periode ini terjadi perubahan mendasar dari kebijakan moneter yang lebih fokus dalam menjaga stabilitas harga. Hal ini juga didasarkan oleh keluarnya Undang-undang Nomor 23 tahun 1999 tentang Independensi Bank Indonesia, dalam artian Bank Indonesia lebih berada pada posisi sebagai partner pemerintah dalam mencapai tujuan pembangunan tanpa adanya intervensi dari pemerintah.

Pertumbuhan kredit dan suku bunga selama periode sebelum otonomi daerah memiliki arah hubungan negatif (trade off) dengan laju inflasi di daerah penelitian. Suku bunga selama periode sebelum otonomi daerah menurunkan laju inflasi dari sisi penawaran, sedangkan pertumbuhan kredit menurunkan laju inflasi dari sisi permintaan. Sedangkan arah hubungan antara pertumbuhan dana yang dihimpun dari masyarakat menunjukkan hubungan positif. Semakin naik DPK akan semakin menurunkan jumlah uang yang beredar di daerah, sehingga pada akhirnya mendorong laju inflasi jika aggregat demand naik.

Selama periode penerapan kebijakan otonomi daerah hanya pengeluaran rutin (ER) dan suku bunga yang signifikan dalam mempengaruhi inflasi. Sehingga dapat disimpulkan bahwa selama periode penerapan kebijakan otonomi daerah tidak terdapat dominasi kebijakan dalam mempengaruhi inflasi, meskipun taraf signifikansi kedua variabel tersebut berbeda. Variabel belanja rutin yang tidak dikendalikan berpotensi memicu terjadinya inflasi. Dengan demikian dapat dikatakan pengeluaran rutin tersebut dapat memicu kenaikan aggregat demand, yang kemudian menciptakan inflasi dari dorongan permintaan (demand pull inflation). Sedangkan suku bunga riil dapat dikatakan mampu menurunkan tingkat inflasi. Setiap kenaikan 1\% dari suku bunga, secara hitungan statistik ekonometrika mampu menurunkan inflasi di daerah sebesar $0,35 \%$. 


\section{IV.4. Pengaruh Variabel-variabel Kebijakan terhadap PDRB Riil}

Pertumbuhan PDRB riil merupakan salah satu tujuan pembangunan. Selama kurun waktu 10 tahun, perubahan signifikan PDRB riil dipengaruhi oleh PAD, pengeluaran pembangunan, DPK, suku bunga riil, dan kredit. Kebijakan moneter selama periode 10 tahun terakhir mampu mendominasi variasi perubahan PDRB riil. Kebijakan moneter yang diikuti dengan perubahan independensi Bank Indonesia mampu memberikan pengaruh yang cukup berarti terhadap perekonomian daerah-daerah di Jawa Timur. Akan tetapi, jika di tinjau dari sudut pandang perubahan kebijakan dan shock perekonomian, apa yang telah di ungkapkan diatas terdapat perberbedaan. Adapun perbandingan antar periode atas dasar perubahan kebijakan dan shock perekonomian dapat dirangkum dalam Tabel IV.8. sebagai berikut :

Arah Hubungan Variabel-variabel Kebijakan dengan Pertumbuhan Ekonomi Regional
di Jawa Timur

Pada keseluruhan periode penelitian, kebijakan moneter memiliki pengaruh yang dominan terhadap pertumbuhan ekonomi di Jawa Timur. Suku bunga dan pertumbuhan PAD memiliki pengaruh positif terhadap pertumbuhan ekonomi. Kenaikan PAD memiliki pengaruh pada pengeluaran pemerintah daerah yang harus dikeluarkan untuk pembiayaan anggaran, baik pembiayaan rutin maupun pembiayaan pembangunan. Dengan demikian, naik-turunnya PAD juga berimplikasi pada pertumbuhan ekonomi regional di Jawa Timur.

Demikian pula dengan pengaruh suku bunga yang positif terhadap petumbuhan ekonomi. Setiap kenaikan suku bunga sebesar $1 \%$ memiliki pengaruh pada pertumbuhan ekonomi sebesar $0,21 \%$. Kenaikan suku bunga tersebut berlawanan dengan teori, namun perlu diingat juga bahwa data yang digunakan dalam penelitian ini adalah suku bunga riil. Berlawanannya temuan ini dimungkinkan karena suku bunga yang berlaku dimasyarakat secara riil adalah minus, sehingga besarnya dana yang dipinjam dari perbankan memiliki nilai yang lebih tinggi daripada nilai nominalnya. 
Lain halnya dengan suku bunga dan PAD, pertumbuhan DPK memiliki arah pengaruh negatif terhadap pertumbuhan ekonomi. Selama keseluruhan periode, DPK yang tidak tersalurkan dengan baik mambawa implikasi pada turunnya pertumbuhan ekonomi

Selama periode sebelum terjadinya krisis ekonomi pertumbuhan DPK dan suku bunga riil signifikan dalam mempengaruhi pertumbuhan PDRB riil. Sedangkan selama periode setelah krisis ekonomi, pertumbuhan PAD, pengeluaran rutin, DPK dan suku bunga riil signifikan dalam mempengaruhi pertumbuhan PDRB riil. Dengan demikian, selama periode sebelum dan sesudah krisis ekonomi, kebijakan moneter lebih dominan dalam mempengaruhi pertumbuhan PDRB riil. Akan tetapi selama periode setelah krisis ekonomi terdapat dua variabel kebijakan fiskal regional yang signifikan mempengaruhi PDRB riil yaitu pertumbuhan PAD dan pengeluaran rutin. Sehingga dapat disimpulkan bahwa upaya pemulihan ekonomi secara regional juga di pengaruhi oleh kebijakan fiskal regional.

Sedangkan selama periode sebelum dan sesudah adanya perubahan kebijakan, dengan dikeluarkannya Undang-Undang Nomor 22 tahun 1999 tentang Pemerintahan Daerah dan Undang-Undang Nomor 25 tahun 1999 tentang Perimbangan Keuangan Pusat-Daerah di bahas dalam bagian ini. Selama periode sebelum dikeluarkannya kedua undang-undang tersebut (sebelum otonomi daerah), perubahan PDRB riil lebih didominasi oleh pengaruh kebijakan moneter yaitu pertumbuhan DPK, dan suku bunga riil. Hal ini sangat mungkin terjadi karena dalam periode ini terdapat shock perekonomian yang menuntut efektifitas kebijakan moneter dalam mempengaruhi stabilitas harga, khususnya pada tahun 1998 - 1999.

Kebijakan moneter dan kebijakan fiskal setelah diterapkannya kebijakan otonomi daerah, tidak memiliki pengaruh yang signifikan dalam mempengaruhi pertumbuhan PDRB riil. Variabelvariabel non-moneter dan variabel non-fiskal lebih menentukan variasi pada pertumbuhan ekonomi regional. Tidak signifikannya variabel-variabel kebijakan moneter dan kebijakan fiskal dimungkinkan karena selama periode otonomi daerah masing-masing daerah dituntut untuk mengelola dan memenuhi kebutuhan daerahnya, sesuai dengan potensi-potensi yang dimiliki, sedangkan ketergantungan terhadap dana dari pusat sedikit banyak telah dilakukan reduksi sesuai dengan diberlakukannya Undang-Undang Nomor 25 tahun 1999 tentang Perimbangan Keuangan Pusat-Daerah. Sedangkan disisi lain, kebijakan moneter masih bersifat sentralistis ditentukan oleh otoritas moneter. Sehingga upaya untuk singkronisasi antara kebijakan fiskal regional dan kebijakan moneter semakin sulit dilakukan.

Selama keseluruhan periode dan keseluruhan bagian penelitian, menujukkan bahwa pertumbuhan pengeluaran pembangunan dan pertumbuhan kredit tidak memiliki pengaruh yang cukup berarti dalam menunjang pertumbuhan ekonomi. Hal ini mengindikasikan bahwa kebijakan fiskal regional ekspansif melalui pengeluaran pembangunan masih belum efektif, 
meskipun pada periode otonomi daerah. Demikian pula dengan kebijakan moneter dengan instrumen kredit masih belum direspon positif oleh pertumbuhan ekonomi regional di Jawa Timur. Sehingga perubahan dari sentralisasi fiskal ke desentralisasi fiskal tidak memiliki pengaruh yang cukup bararti dalam mempengaruhi pertumbuhan ekonomi. Sedangkan dari sisi variabel moneter, perlu untuk menerapakan kebijakan mendorong investasi yang lebih efektif dan intensif kepada masyarakat dengan menyalurkan kredit yang lebih dari sebelumnya.

\section{KESIMPULAN DAN SARAN}

\section{V.1. Kesimpulan}

Setelah melalui proses analisis dan pembahasan data, penulis memperoleh beberapa kesimpulan sebagai berikut :

1) Selama periode penelitian, kondisi krisis ekonomi dan kebijakan baru (otonomi daerah) memiliki pengaruh yang berarti terhadap stabilitas harga dan pertumbuhan ekonomi regional di Jawa Timur.

2) Selama periode penelitian, keseluruhan variabel kebijakan moneter dan kebijakan fiskal secara bersama-sama memiliki pengaruh yang signifikan terhadap stabilitas harga dan pertumbuhan ekonomi regional di Jawa Timur. Akan tetapi dalam empat bagian periode penelitian, terdapat perbedaan dalam tingkat signifikansi variabel moneter dan variabel fiskal dalam mempengaruhi pertumbuhan ekonomi dan inflasi di Jawa Timur.

Selama periode sebelum krisis ekonomi, inflasi signifikan dipengaruhi hampir oleh keseluruhan variabel independen, hanya variabel pertumbuhan pengeluaran rutin yang tidak signifikan mempengaruhi inflasi regional di Jawa Timur. Sedangkan dalam periode yang sama, pertumbuhan ekonomi signifikan dipengaruhi hanya oleh pertumbuhan dana yang dihimpun oleh perbankan didaerah dan suku bunga riil. Selama periode krisis ekonomi, hanya variabel pertumbuhan PAD, pertumbuhan pengeluaran rutin, pertumbuhan DPK dan suku bunga riil yang signifikan dalam mempengaruhi inflasi regional di Jawa Timur. Sedangkan selama periode yang sama hanya pertumbuhan pendapatan asli daerah, pertumbuhan pengeluaran rutin, pertumbuhan dana yang dihimpun perbankan dari pihak ketiga didaerah dan suku bunga riil signifikan dalam mempengaruhi pertumbuhan ekonomi.

Selama periode sebelum otonomi daerah, variabel pertumbuhan dana pihak ketiga, pertumbuhan kredit dan suku bunga riil di daerah yang signifikan dalam mempengaruhi inflasi di daerah penelitian. Sedangkan pertumbuhan ekonomi di daerah penelitian signifikan dipengaruhi hanya oleh pertumbuhan dana pihak ketiga, suku bunga riil perbankan didaerah. 
Selama periode penerapan otonomi daerah, fenomena inflasi dan pertumbuhan ekonomi berbeda dengan periode sebelum penerapan otonomi daerah.

Selama periode ini, inflasi signifikan hanya dipengaruhi oleh pertumbuhan pengeluaran rutin dan suku bunga. Sedangkan selama periode yang sama, variabel-variabel moneter dan variabel fiskal regional tidak memiliki pengaruh signifikan dalam mempengaruhi pertumbuhan ekonomi regional di Jawa Timur. Selama periode penerapan otonomi daerah, pertumbuhan ekonomi regional di Jawa Timur lebih dipengaruhi oleh variabel lain.

3) Analisis secara keseluruhan membuktikan bahwa kebijakan moneter dan kebijakan fiskal regional relatif berimbang dalam mempengaruhi stabilitas harga di Jawa Timur. Akan tetapi tidak demikian dengan pengaruh kebijakan moneter dan kebijakan fiskal regional dalam mepengaruhi pertumbuhan PDRB riil di Jawa Timur, dimana kebijakan moneter lebih menentukan variasi perubahan PDRB riil di Jawa Timur. Hal ini dikarenakan frekuensi data kebijakan moneter lebih tinggi daripada frekuensi data kebijakan fiskal regional.

Tidak dominannya kebijakan fiskal dalam mempengaruhi pertumbuhan ekonomi di Jawa Timur disebabkan juga oleh masa tunggu perubahan-perubahan yang terjadi pada kebijakan fiskal, dimana kebijakan fiskal ditentukan setiap tahun sekali dan membutuhkan banyak pertimbangan oleh pemegang kebijakan. Sedangkan kebijakan moneter dapat segera ditentukan oleh otoritas moneter melalui instrumen-instrumen kebijakan moneter yang ada, baik melalui SBI maupun oleh instrumen-instrumen lainnya. Suatu temuan yang cukup menarik, dimana selama periode otonomi daerah tidak terdapat variabel kebijakan moneter dan variabel kebijakan fiskal yang mempengaruhi pertumbuhan ekonomi regional di Jawa Timur. Hal ini menunjukkan bahwa selama periode otonomi daerah fungsi stabilisasi kebijakan yang semakin komplek dan sulit dilakukan.

\section{V.2. Saran}

Setelah melalui beberapa tahapan analisis dalam penelitian ini, maka diperoleh beberapa saran yang berkaitan dengan implikasi kebijakan, diantaranya:

1. Untuk mencapai tujuan stabilitas harga dan pertumbuhan ekonomi yang berkelanjutan di daerah, diperlukan keselarasan antara kebijakan moneter dan kebijakan fiskal baik regional maupun nasional. Kebijakan pencapaian tujuan pembangunan oleh pemerintah daerah perlu dikoordinasikan dengan program pengendalian inflasi (inflation targeting) oleh Bank Indonesia. Mengingat secara keseluruhan, selama periode otonomi daerah varaibel-variabel kebijakan moneter dan kebijakan fiskal regional tidak memiliki pengaruh yang berarti dalam menunjang pertumbuhan ekonomi di Jawa Timur. 
2. Lebih dominannya kebijakan moneter dalam mempengaruhi stabilitas harga dan pertumbuhan ekonomi regional di Jawa Timur, semakin memberi kesempatan bagi otoritas moneter untuk mencapai tujuan-tujuan pembangunan. Otoritas moneter dapat menggunakan instrumen suku bunga dalam mempengaruhi inflasi dan instrumen kredit dalam mempengaruhi pertumbuhan ekonomi regional, baik di daerah Jawa Timur maupun daerah-daerah lainnya, karena sifat kebijakan moneter yang memang harus sentralistis.

3. Kebijakan inflation targeting perlu untuk dilanjutkan, meskipun perlu adanya perbaikan. Mengingat instrumen suku bunga yang selalu berpengaruh terhadap inflasi pada keseluruhan periode penelitian, baik periode sebelum dan sesudah krisis ekonomi maupun sebelum dan sesudah diterapkannya otonomi daerah. Hal ini membuktikan bahwa suku bunga memang efektif mempengaruhi laju inflasi pada keseluruhan periode penelitian.

4. Dari sisi pertumbuhan kredit, perlu untuk melakukan revitalisasi investasi oleh sektor perbankan. Hal ini dikarenakan selama keseluruhan periode penelitian, variabel kredit tidak memiliki pengaruh yang berarti terhadap pertumbuhan ekonomi. Koordinasi antara pemerintah daerah, perbankan di daerah dan Bank Indonesia perlu dilakukan untuk memberikan kemudahan investasi. Sehingga dengan naiknya investasi diharapkan kredit mampu menunjang pertumbuhan ekonomi regional.

5. Pengeluaran pembangunan perlu untuk ditingkatkan efektifitas, efisiensi dan intensitasnya dalam mendorong pertumbuhan ekonomi regional di Jawa Timur. Mengingat secara keseluruhan periode penelitian maupun bagian-bagian periode penelitian yang menunjukkan pengeluaran pembangunan tidak memiliki pengaruh yang signifikan dalam mempengruhi pertumbuhan ekonomi regional di Jawa Timur. Lebih rendahnya pengeluaran pembangunan daripada pengeluaran rutin menunjukkan bahwa kebijakan pemerintah daerah dalam hal pembangunan masih belum efektif dalam mempengaruhi pertumbuhan ekonomi reional di Jawa Timur.

6. Perlunya kajian ulang pada kebijakan pemerintah daerah dalam hal tingginya pertumbuhan pengeluaran rutin. Hal ini dikarenakan selama periode penerapan otonomi daerah, pengeluaran rutin signifikan dalam mendorong tingginya laju inflasi regional di Jawa Timur. Variabel pengeluaran rutin yang tidak dikendalikan akan memicu tingginya aggregat demand sehingga laju inflasi yang tinggi dapat terjadi.

7. Dengan kemajuan pelaksanaan otonomi daerah, kedepan diharapakan BPS di daerah dan kantor-kantor perwakilan Bank Indonesia di daerah mampu menyediakan data yang lebih komprehensif dan menyediakan informasi yang lebih mudah untuk diakses masyarakat. Hal ini dikarenakan kemudahan data dan informasi-informasi yang disediakan BPS dan BI di 
daerah setidaknya sebagai penunjang kebijakan inflation targetingyang diterpakan BI dewasa ini. Disamping juga perkembangan ekonomi yang semakin mudah untuk diketahui oleh masyarakat jika data-data dan informasi yang ada di daerah mudah untuk diketahui oleh masyarakat dan pelaku-pelaku ekonomi. 


\section{DAFTAR PUSTAKA}

Afin, Rifai. 2006. Stabilitas Dan Dispersi Harga Dalam Skema Otonomi Daerah Di Indonesia (Pendekatan Model Cross Section Dan Model Dispersi). Makalah adalah Back Ground Paper dalam Kongres ISEI ke 16 di Manado. 19 - 21 Juni 2006.

Afin, Rifai dan Rumayya. 2005. "Convergence in Price Level Among East Java's Region". Makalah disampaikan dalam 7th Indonesian Regional Science Association (IRSA) International Conference. August, 3-4, 2005. Economics Faculty University of Indonesia. Jakarta.

Aliman. 2003. "Analisis Penerapan Kebijakan Moneter dan Kebijakan Fiskal di Indonesia". Jurnal Ekonomi dan Bisnis Indonesia.

Arif, Sritua. 1993. Metodologi Penelitian Ekonomi. Jakarta : UI Press.

Badan Analisa Fiskal. 2004. Kebijakan Fiskal : Pemikiran Konsep dan Implementasi. Badan Analisa Fiskal Departemen Keuangan. Jakarta : Departemen Keuangan.

Badan Analisa Fiskal Dan Japan International Cooperation Agency. 2002. Bunga Rampai Kebijakan Fiskal. Badan Analisa Fiskal Departemen Keuangan. Jakarta : Departemen Keuangan.

Baltagi, Badi H. 2002. Econometric Analysis of Panel Data. Second Edition. New York : John Wiley \& Sons. Ltd.

Bank Indonesia. Statistik Ekonomi dan Keuangan Indonesia. Berbagai edisi penerbitan dan website : www.bi.go.id . Jakarta : Bank Indonesia.

Bank Indonesia. Statistik Ekonomi dan Keuangan Daerah. Berbagai edisi penerbitan. Surabaya : Bank Indonesia.

Basri, Yuswar Z dan Mulyadi Sabri. 2003. Keuangan Negara dan Analisis Kebijakan Utang Luar Negeri. Jakarta : PT. Rajawali Grafindo Persada

Biro Pusat Statistik. Indikator Ekonomi Jawa Timur. Berbagai edisi penerbitan. Surabaya : Biro Pusat Statistik.

Biro Pusat Statistik. Produk Domestik Bruto Kabupaten dan Kota di Jawa Timur. Berbagai edisi penerbitan. Surabaya : Biro Pusat Statistik 
Budi, Riski Satya dan Frita Amrita. 2006. Stabilitas Harga, Konvergensi Inflasi dan Otonomi Daerah di Indonesia. Makalah Lomba Karya Tulis Mahasiswa Bank Indonesia 2005. Tidak dipublikasikan.

Budiono. 1985. Uang dan Bank. Edisi 4. Yogyakarta : BPFE UGM

Departemen Keuangan. Laporan Realisasi Anggaran Pendapatan Belanja Daerah. Berbagai edisi penerbitan. www.depkeu.go.id. Diakses tanggal 31 Maret 2006. Jakarta : Departemen Keuangan

Enders, Walter. 1995. Applied Econometric Time Series. Iowa University. New York : John Wiley and Sons. Inc.

Cargill, TF. 1991. Money, The Financial Sistem and Monetary Policy. New York : Printice Hall Inc. Gujarati, Damodar N. 2003. Basic Econometrics. Fourth Edition. New York : McGRAW-HILL Iswardono, 1997. Uang dan Bank. Edisi 4. Yogyakarta : BPFE UGM

Maddala, G.S. 1993. The Econometrics of Panel Data. Volume I. New York : Edward Elgar Publising Limited.

Mankiw, N. Gregory. 2000. Teori Makro Ekonomi. Edisi Keempat. Terjemahan. Jakarta : Penerbit Erlangga

Mishkin, Frederic S. 2004. The Economy of Money, Banking \& Financial Market. Seventh Edition. New York : Columbia University Press

Nopirin. 1992. Ekonomi Moneter 2. Yogyakarta: BPFE UGM.

Pindyck, Robert S. 1998. Daniel L. Rubinfeld, Econometric Models and Economic Forecasting, 4rd Edition. New York : McGraw-Hill.

Simorangkir, Iskandar. dkk. 2005. Identifikasi faktor-faktor Penentu Inflasi Regional Dalam Era Otonomi Daerah. Pusat Pendidikan dan Kebanksentralan, Bank Indonesia, Deseminasi hasil penelitian di Unair Surabaya.

Sriwiyanto, Hery Sulistio Jati Nugroho dan Tetuko Rawidyo Putro. 2006. Tantangan Dan Prospek Implementasi Kebijakan Stabilitas Harga Model New Keynesian Monetary Policy Dalam Perspektif Otonomi Daerah: Pembuktian Empiris Di 40 Pemerintah Kota Di Indonesia (19932003). Makalah Disampaikan dalam Kongres ISEI ke 16 di Manado. 19 - 21 Juni 2006.

Suparmoko. 1999. Pengantar Ekonomi Makro. Edisi Empat. Yogyakarta: BPFE UGM. 
Undang-Undang Nomor 22 tahun 1999 tentang Pemerintahan Daerah Undang-Undang Nomor 25 tahun 1999 tentang Perimbangan Keuangan Pusat-Daerah Undang-undang Nomor 23 tahun 1999 tentang Independensi Bank Indonesia Undang-Undang Nomor 32 tahun 2004 tentang Pemerintahan Daerah Undang-Undang Nomor 33 tahun 2004 tentang Perimbangan Keuangan Pusat-Daerah Quantitatif Micro Soft Ware. 2002. Eviws 4.1. User Guide. United States of America : Quantitatif Micro Soft Ware. LLC 2005. Modul Pelatihan Ekonometrika Dasar. Kerjasama Laboratorium FE UI dan Direktorat Pendidikan Tinggi. Jakarta : Departemen Pendidikan Nasional. 2004. Modul Pelatihan Ekonometrika dan Time Series Models. Jurusan Ilmu Ekonomi dan Studi Pembangunan, Fakultas Ekonomi Universitas Airlangga. Surabaya 
